\title{
Holocene vegetation and biomass changes on the Tibetan Plateau - a model-pollen data comparison
}

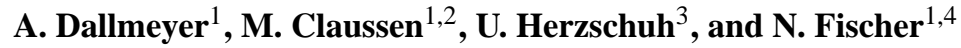 \\ ${ }^{1}$ Max Planck Institute for Meteorology, KlimaCampus Hamburg, Germany \\ ${ }^{2}$ Meteorological Institute, University of Hamburg, KlimaCampus Hamburg, Germany \\ ${ }^{3}$ Alfred Wegener Institute for Polar and Marine Research, Potsdam, Germany \\ ${ }^{4}$ International Max-Planck-Research School, Hamburg, Germany
}

Received: 17 February 2011 - Published in Clim. Past Discuss.: 31 March 2011

Revised: 19 July 2011 - Accepted: 28 July 2011 - Published: 12 August 2011

\begin{abstract}
Results of a transient numerical experiment performed in a coupled atmosphere-ocean-vegetation model with orbital forcing alone are compared to pollen-based vegetation reconstructions covering the last $6000 \mathrm{yr}$ from four representative sites on the Tibetan Plateau. Causes of the vegetation change and consequences of the biomass storage are analysed.

In general, simulated and reconstructed vegetation trends at each site are in good agreement. Both methods reveal a general retreat of the biomass-rich vegetation that is particularly manifested in a strong decrease of forests. However, model and reconstructions often differ with regard to the climatic factors causing the vegetation change at each site. The reconstructions primarily identify decreasing summer monsoon precipitation and changes in the temperature of the warm season as the responsible mechanisms for the vegetation shift. In the model, the land cover change mainly originates from differences in warm/cold seasonal temperatures and only to a lesser extent from precipitation changes.

According to the model results, the averaged forest fraction on the Plateau shrinks by almost one-third from midHolocene $(41.4 \%)$ to present-day $(28.3 \%)$. Shrubs, whose fraction is quadrupled at present-day $(12.3 \%)$, replace most of this forest. Grass fraction increases from $38.1 \%$ during the mid-Holocene to $42.3 \%$ at present-day. This land cover change results in a decrease of living biomass by $0.62 \mathrm{kgC} \mathrm{m}^{-2}$. Total biomass on the Tibetan Plateau decreases by $1.9 \mathrm{kgC} \mathrm{m}^{-2}$, i.e. approx. $6.64 \mathrm{PgC}$ are released due to the natural land cover change.
\end{abstract}

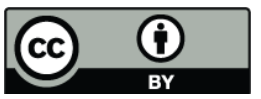

Correspondence to: A. Dallmeyer (anne.dallmeyer@zmaw.de)

\section{Introduction}

The Tibetan Plateau covers a region of approx. 2.5 million $\mathrm{km}^{2}$. With an average height of more than $4000 \mathrm{~m}$ above sea level (a.s.l.), it penetrates deep into the troposphere reaching atmospheric levels of less than $500 \mathrm{hPa}$. Due to its large horizontal and vertical extent, the Tibetan Plateau affects the regional as well as the global climate, including the circulation, energy, and water cycle (Wu et al., 2007). Besides the mechanical blocking of zonal as well as meridional atmospheric flow (e.g. Wu et al., 2005; Y. Liu et al., 2007), thermal processes on the Tibetan Plateau strongly influence the regional circulation.

Regarding the influence of the land cover of the Tibetan Plateau on climate, the following aspects are particularly important:

- Elevated heat source: acting as a heat source for the atmosphere in spring and summer, the Tibetan Plateau plays an important role for the onset and maintenance of the Asian summer monsoon (e.g. Wu and Zhang, 1998; Ye and $\mathrm{Wu}, 1998 ; \mathrm{Wu}, 2004$; Y. Liu et al., 2007).

- Huge air-pump: the large amount of air pumped up in the atmosphere above the Tibetan Plateau due to high convective activity diverges near the tropopause and subsides in North Africa, Central Asia, and the Middle East. Thereby, the large-scale subsidence forces and forms dry climates and deserts such as the Sahara, Taklamakan Desert, and Dzungar Desert (Rodwell and Hoskins, 1996; Ye and Wu, 1998; Duan and Wu, 2005).

- Variations in the surface temperature: recent studies propose a strong relationship between the heating on the Plateau and the summer monsoon rainfall in East Asia

Published by Copernicus Publications on behalf of the European Geosciences Union. 
(e.g. Hsu and Liu, 2003; Yanai and Wu, 2006; Zhang et al., 2006; Wang et al., 2008). Investigations based on observations as well as climate model sensitivity experiments suggest an enhancement of the moisture transport towards East Asia and increasing precipitation in the subtropical front (Mei-Yu, Baiu, and Changma) in years with higher surface temperature on the Tibetan Plateau (Wang et al., 2008).

- Accumulation of snow: high-elevation snow accumulation is another important factor by which the Tibetan Plateau exerts influence on the Asian climate. Abovenormal snow cover in winter weakens the land-sea temperature gradient and attenuates the East Asian monsoon in the subsequent summer (Y. Liu et al., 2007).

All these processes depend to a large part on the land cover of the Tibetan Plateau as it modulates the energy balance and energy transfer between the atmosphere and the land surface (Yasunari, 2007). The albedo of the surface determines the absorbed incoming solar radiation and therewith the strength of diabatic heat fluxes. Changes in the Tibetan Plateau's land cover may thus exert strong influence on the regional and even on the Northern Hemispheric climate and atmospheric circulation.

Beside the biogeophysical effects of changing albedo, surface roughness, and evapotranspiration, land cover changes affect the climate via biogeochemical feedbacks, for example by the emission of carbon into the atmosphere (Claussen et al., 2001). Therefore, it is necessary to get more information about land cover changes on the Tibetan Plateau to understand past climate change in Asia.

So far, reconstructions suggest an increased mid-Holocene forest fraction on the eastern and southern margin of the Plateau compared to the present conditions (Shen et al., 2005, 2006). Enlarged monsoon rainfall and higher summer temperatures due to orbitally-induced insolation changes are seen as the most important forcing mechanisms for the vegetation change (Herzschuh et al., 2010a), but human impact is discussed as an influencing factor as well (Schlütz and Lehmkuhl, 2009). For the central Tibetan Plateau, reconstructions reveal only slight changes in vegetation composition during the Holocene (Tang et al., 2009). Fewer records are available for the western Tibetan Plateau. They indicate wetter climate conditions (Gasse et al., 1991) and more vegetation for the mid-Holocene.

As pollen reconstructions can only illustrate the local vegetation distribution and can only be taken as proxies for climate change, it is important to perform model simulations to identify the mechanism behind the changes. Furthermore, Earth System Models (ESM) have the advantage of calculating area-wide vegetation and climate changes, taking feedback mechanisms into account (Kleinen et al., 2011). Thereby, it is possible to extract the driving parameters regarding the Holocene climate and vegetation change on the Tibetan Plateau and surrounding monsoonal areas; even more, related changes in the terrestrial carbon storage can be quantified.

Since computing power is limited, long transient experiments in comprehensive Earth system models can only be performed with coarse numerical resolutions. Such an experiment has been conducted by Fischer and Jungclaus (2011) with the model ECHAM5/JSBACH-MPIOM, covering the last $6000 \mathrm{yr}$.

The primary aim of this study is to critically assess the performance of that model with respect to the land cover on the Tibetan Plateau. For this purpose, we compare pollen-based vegetation reconstructions for different sites on the Plateau with the simulated potential vegetation trend in the surrounding areas. Anthropogenic land use changes are not taken into account by the model. Secondly, we want to identify the specific climatic parameters that caused the past vegetation changes. Thirdly, we quantify the total changes of simulated vegetation carbon storage for the entire Tibetan Plateau.

\section{Study area}

\subsection{The Tibetan Plateau}

The Tibetan Plateau covers almost one-sixth of the area in China. Located in a tectonically active region (ca. $80-105^{\circ} \mathrm{E}$ and $27-37^{\circ} \mathrm{N}$ ), the Plateau exhibits a highly complex orography with steep and huge mountain ranges as well as large elevated plains. The Tibetan Plateau penetrates deep into the troposphere. Thus, it shows unique climate conditions with the lowest surface temperature and pressure as well as highest 10-m wind speed compared to areas in the same latitudinal belt (Asnani, 1993).

Following the general decrease in altitude, near-surface air temperature and precipitation increase from the northwestern to the south-eastern part of the Plateau. In summer, the Plateau is characterised by near-surface air temperatures up to $19^{\circ} \mathrm{C}$ in the south-east and ca. $6^{\circ} \mathrm{C}$ in the northwest (Sun, 1999). Winter temperatures are around $5-10^{\circ} \mathrm{C}$ in the south-east and $-25^{\circ} \mathrm{C}$ in the north-west (Cui and Graf, 2009). Due to the strong insolation during daytime, nearsurface air temperatures experience strong diurnal variations. Surface soil temperature varies up to $50^{\circ} \mathrm{C}$ (during spring) between day and night (Cui and Graf, 2009).

Annual precipitation ranges from approximately $700 \mathrm{~mm}$ in the south-eastern part to less than $100 \mathrm{~mm}$ in the northwestern part (Sun, 1999), and precipitation also strongly varies in time and space (Ueno et al., 2001). Besides the orography, precipitation distribution on the Tibetan Plateau is strongly determined by the large-scale atmospheric circulation. The southern and eastern parts are affected by the Asian summer monsoon (Fig. 1a) that provides more than $80 \%$ of the annual total (Cui and Graf, 2009). The northern parts are affected by the westerly wind circulation bearing less precipitation. 

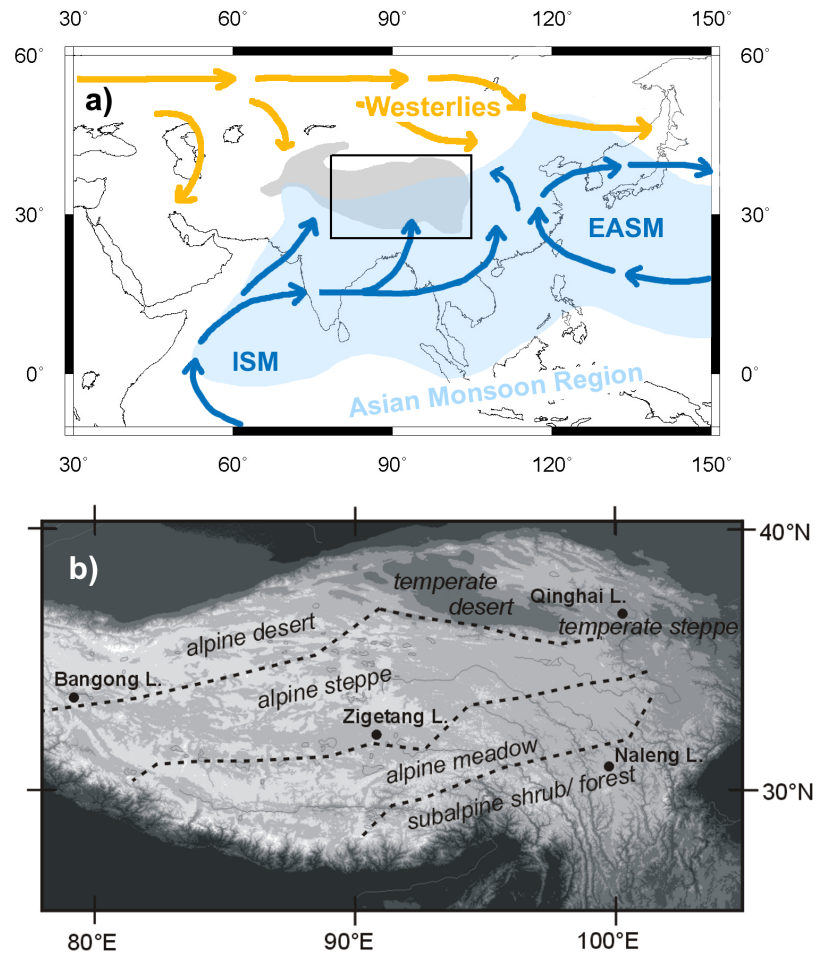

Fig. 1. (a) Sketch of the main atmospheric circulation systems (in $850 \mathrm{hPa}$ ) affecting the Tibetan Plateau (grey-shaded) during the summer monsoon season, based on observations: westerly wind circulation (orange), Indian summer monsoon circulation (ISM, blue) and East Asian summer monsoon circulation (EASM, blue). Light blue shaded region marks the Asian monsoon domain; (b) shows the area marked as black rectangle in (a) and displays the distribution of the main vegetation types on the Tibetan Plateau (modified from Hou, 2001) and locations of the different study sites.

The diverse climate conditions lead to a unique land cover on the Plateau. Strong temperature and precipitation gradients along the steep mountains offer a very heterogeneous environment for vegetation, but make the located vegetation also highly susceptible to climate change.

The spatial distribution of major vegetation types is described in the Vegetation Atlas of China (Hou, 2001) and summarised in Fig. 1b. Present-day vegetation along the wet and warm south-eastern and eastern margins of the Tibetan Plateau is dominated by montane conifer and broad-leaved forests. However, loss of natural forest since at least during the past $2000 \mathrm{yr}$ and even more intense since the 1950s is attributed to anthropogenic forest clearance as a consequence of the high timber, grazing, and agricultural ground demand of a constantly growing population (Studley, 1999; Zhang et al., 2000; Dearing et al., 2008; Wischnewski et al., 2011). Only during the last three decades have reforestation programs and a logging ban stopped the further forest loss in these areas (Zhang et al., 2000; Fang et al., 2001). Above the treeline (ca. 3000-4000 m), sub-alpine shrubs cover the area, replaced by alpine and high-alpine meadows at higher elevations. The dry north-eastern and central Tibetan Plateau is characterised by temperate and alpine steppe vegetation. Alpine deserts form the landscape at the dry north-central and western Plateau.

\subsection{Study sites for pollen-based vegetation reconstructions}

In this study, pollen records from four different lakes are considered, representing different climate and vegetation zones on the Tibetan Plateau (see Fig. 1). These are Lake Qinghai and Lake Naleng on the north-eastern and south-eastern Tibetan Plateau, respectively, as well as Lake Zigetang on the central and Lake Bangong on the western Tibetan Plateau.

Lake Qinghai $\left(36.55^{\circ} \mathrm{N}, 100.1^{\circ} \mathrm{E}, 3200 \mathrm{~m}\right.$ a.s.l. $)$ has a surface area of about $4400 \mathrm{~km}^{2}$ and is the largest saline lake in China. Located at the north-eastern Tibetan Plateau and therewith in the fringe area of the Asian monsoon, the climate around the lake is influenced by three planetary-scale circulation systems: the region is not only characterised by the East Asian and Indian monsoon, but also affected by the westerly atmospheric flow (Xu et al., 2007). Thus, changes in climate, in particular the monsoon intensity, probably have a strong impact on the regional vegetation composition. Nowadays, the lake lies in the semi-arid and moderate cold climate zone with mean annual precipitation and temperature reaching approx. $250 \mathrm{~mm} \mathrm{yr}^{-1}$ and $-0.7^{\circ} \mathrm{C}$, respectively (Shen et al., 2005). The nearby climate station (Yeniugou, $99.58^{\circ} \mathrm{E}, 38.42^{\circ} \mathrm{E}, 3320 \mathrm{~m}$ a.s.l.) records a mean annual temperature of $-2.5^{\circ} \mathrm{C}$, a mean July temperature of $10^{\circ} \mathrm{C}$ and a mean January temperature of $-16.3^{\circ} \mathrm{C}$.

The vegetation immediately around the lake is characterised by temperate steppes dominated by Artemisia and Poaceae. The reconstructions used in this study are based on a $795 \mathrm{~cm}$ long core (QH-2000) from the south-eastern part of the lake. For further description of the study site, material and dating see Shen et al. (2005).

Lake Naleng $\left(31.1^{\circ} \mathrm{N}, 99.75^{\circ} \mathrm{E}, 4200 \mathrm{~m}\right.$ a.s.l. $)$ is a medium-sized freshwater lake on the south-eastern Tibetan Plateau (area: $1.8 \mathrm{~km}^{2}$ ). The pronounced relief and steep elevations in its environment lead to strong climatic and vegetational gradients. The climate around the lake is influenced by the Asian monsoon, yielding $90 \%$ of the annual precipitation (ca. $630 \mathrm{~mm} \mathrm{yr}^{-1}$ at a nearby climate station). The mean July temperature at the lake is ca. $7.4^{\circ} \mathrm{C}$. Mean annual temperature is approximately $1.6^{\circ} \mathrm{C}$ (Kramer et al., 2010). Lake Naleng is situated at the upper tree line composed of Picea; the (sub-)alpine vegetation is composed of shrubs such as Potentila, Spiraea, Rhododendron intermixed with Kobresia dominated meadows. Due to its location, climate change especially variability in temperature - is expected to cause strong shifts in regional vegetation. The vegetation trend at this site is analysed based on the upper part of a $17.8 \mathrm{~m}$-long 
sediment core. Details of the study site, materials, and methods are described in Kramer et al. (2010).

Lake Zigetang $\left(32^{\circ} \mathrm{N}, 90.9^{\circ} \mathrm{E}\right.$, ca. $4500 \mathrm{~m}$ a.s.1.) is a large saline lake (surface area ca. $190 \mathrm{~km}^{2}$ ) on the high-altitude inner Tibetan Plateau. The regional climate is cold and semi-arid, but still affected by the Indian monsoon circulation. Mean annual precipitation and temperature ranges from about $300-500 \mathrm{~mm} \mathrm{yr}^{-1}$ and from $-2.6^{\circ} \mathrm{C}$ to $-0.3^{\circ} \mathrm{C}$, respectively. According to Naqu climate station $\left(90.02^{\circ} \mathrm{E}\right.$; $31.48^{\circ} \mathrm{N}, 4500 \mathrm{~m}$ a.s.1.), mean July temperature is $9.5^{\circ} \mathrm{C}$ and mean January temperature is $-12^{\circ} \mathrm{C}$. The vicinity of Lake Zigetang is covered by alpine steppe (dominated by Poaceae and Artemisia), but vegetation turns to alpine Kobresia meadows to the east of the lake. Further details are described in Herzschuh et al. (2006).

With a surface area of $604 \mathrm{~km}^{2}$, Lake Bangong $\left(33.42^{\circ} \mathrm{N}\right.$, $79^{\circ} \mathrm{E}, 4200 \mathrm{~m}$ a.s.l.) is the largest lake on the western Tibetan Plateau. Located in the rain shadow of the Kunlun and Karakorum mountain ranges, climate around the lake is cold and very dry. Temperatures range from $-15.8^{\circ} \mathrm{C}$ in January to $11.9^{\circ} \mathrm{C}$ in July and are ca. $-1.5^{\circ} \mathrm{C}$ in the annual mean. Precipitation originates mainly from the Indian monsoon, but does not exceed $70 \mathrm{~mm} \mathrm{yr}^{-1}$ (van Campo et al., 1996). Accordingly, montane desert/steppe-desert dominates the area characterised by a sparse vegetation cover. Pollen assemblages used in this study are based on a $12.4 \mathrm{~m}$ core from the eastern part of the lake. For further information on the material and site see van Campo et al. (1996) and Fontes et al. (1996).

\section{Methods}

\subsection{General model setup and experimental design}

To estimate the mid- to late-Holocene vegetation change on the Tibetan Plateau, a transient numerical experiment was analysed. The simulation was performed by Fischer and Jungclaus (2011) with the comprehensive Earth system model ECHAM5/JSBACH-MPIOM developed at the MaxPlanck-Institute for Meteorology. The model consists of the atmospheric general circulation model ECHAM5 (Roeckner et al., 2003) coupled to the land-surface scheme JSBACH (Raddatz et al., 2007) and the ocean model MPIOM (Marsland et al., 2003; Jungclaus et al., 2006). JSBACH included the dynamic vegetation module of Brovkin et al. (2009). ECHAM5 ran with 19 vertical levels and a spectral resolution of T31, which corresponds to a latitudinal distance of ca. $3.75^{\circ}$, i.e. a grid-box width of about $354 \mathrm{~km}$ at $32^{\circ} \mathrm{N}$. The ocean-grid had a horizontal resolution of approximately $3^{\circ}$ and 40 vertical levels. The models had been tested against observation and reanalysis data, proving that they capture the major structure of global and regional climate (e.g. Cui et al., 2006).
The transient experiment started at mid-Holocene climate conditions: orbital parameters in the coupled models had been adjusted to the configuration $6000 \mathrm{yr}$ before present (henceforth referred to as $6 \mathrm{k}$ ). Atmospheric composition had been fixed at pre-industrial values with $\mathrm{CO}_{2}$-concentration set to $280 \mathrm{ppm}$. Under these boundary conditions, the model was brought to quasi-equilibrium climate state. Afterwards, the orbital configuration was continuously being changed until present-day $(0 \mathrm{k})$ conditions were reached. During the entire transient run, atmospheric composition stayed constant. The calculated climate change, thus, can be attributed to orbital forcing alone. Biogeochemical processes have no influence on the climate change.

Due to the coarse model resolution, it was not possible to take the geographically nearest grid-boxes around the lakes for the comparison of model results and reconstructions. Simulated present-day climate differs strongly from observations, since the orography in the model is underestimated. Instead we use an average over two to three grid-boxes in the vicinity of each lake showing an analogue vegetation trend (Fig. 2). The grid-boxes have been selected by applying the following criteria: (a) the averaged climate in the grid-boxes represents the local climate at the study site more appropriately (e.g. Lake Qinghai, Lake Zigetang); (b) the grid-boxes are located upstream of the study sites with respect to the atmospheric circulation system effecting the site (e.g. Lake Bangong, Lake Naleng, Lake Zigetang).

\subsection{Dynamic vegetation module}

The dynamic vegetation module used in this study (Brovkin et al., 2009) distinguishes eight plant-functional types (PFTs), i.e. plants are grouped with regard to their physiology, including their leaf phenology type. Trees can be either tropical or extratropical and are further differentiated between evergreen and deciduous trees. The module considers two shrubby vegetation types, namely raingreen shrubs and cold shrubs. The first is limited by moisture; the second represents shrubs limited by temperature. Grass is classified as either $\mathrm{C} 3$ or $\mathrm{C} 4$ grass.

For each PFT, environmental constraints are defined in the form of temperature thresholds representing their respective bioclimatic tolerance. These thresholds define the area where establishment of a PFT is possible. They describe cold resistance by the lowest mean temperature of the coldest month $\left(\mathrm{Tc}_{\min }\right)$, chilling requirements by the maximum mean temperature of the coldest month $\left(\mathrm{Tc}_{\max }\right)$ and heat requirement for the growth phase. The latter is considered via the summation of temperatures over days with temperatures higher than $5^{\circ} \mathrm{C}$, called growing degree days (GDD5). Cold shrubs are also excluded in regions with warm climate $\left(\mathrm{Tw}_{\max }\right)$. The values of the limits are listed in Table 1 and similar to the limits used in the biosphere model LPJ (Sitch et al., 2003).

For each grid-box of the atmosphere, the land surface is tiled in mosaics so that several PFTs can be represented in 
Table 1. Bioclimatic limits for the 8 plant functional types (PFTs) used in the coupled model experiment. Listed are phenology type; PFTspecific minimum of coldest monthly mean temperature $\left(\mathrm{Tc}_{\min }\right)$; PFT-specific maximum of coldest monthly mean temperature $\left(\mathrm{Tc} \mathrm{c}_{\text {max }}\right)$; $\mathrm{PFT}$ specific maximum warmest monthly mean temperature $\left(\mathrm{Tw}_{\max }\right)$; and growing degree days, i.e. temperature sum of days with temperatures exceeding $5^{\circ} \mathrm{C}$ (GDD5). All temperature values are given in ${ }^{\circ} \mathrm{C}$.

\begin{tabular}{lllrrrr}
\hline No. & landcover classification & phenology type & $\mathrm{Tc}_{\min }\left[{ }^{\circ} \mathrm{C}\right]$ & $\mathrm{Tc}_{\max }\left[{ }^{\circ} \mathrm{C}\right]$ & $\mathrm{Tw}_{\max }\left[{ }^{\circ} \mathrm{C}\right]$ & $\mathrm{GDD5}\left[{ }^{\circ} \mathrm{C}\right]$ \\
\hline 1 & tropical evergreen trees & raingreen & 15.5 & - & - & 0 \\
2 & tropical deciduous trees & raingreen & 15.5 & - & - & 0 \\
3 & extratrop. evergreen trees & evergreen & -32.5 & 18.5 & - & 350 \\
4 & extratrop. deciduous trees & summergreen & - & 18.5 & - & 350 \\
5 & raingreen shrubs & raingreen & 0 & - & - & 900 \\
6 & cold shrubs & summergreen & - & -2 & 18 & 300 \\
7 & C3 grass & grasses & - & 15 & - & 0 \\
8 & C4 grass & grasses & 10 & - & - & 0 \\
\hline
\end{tabular}

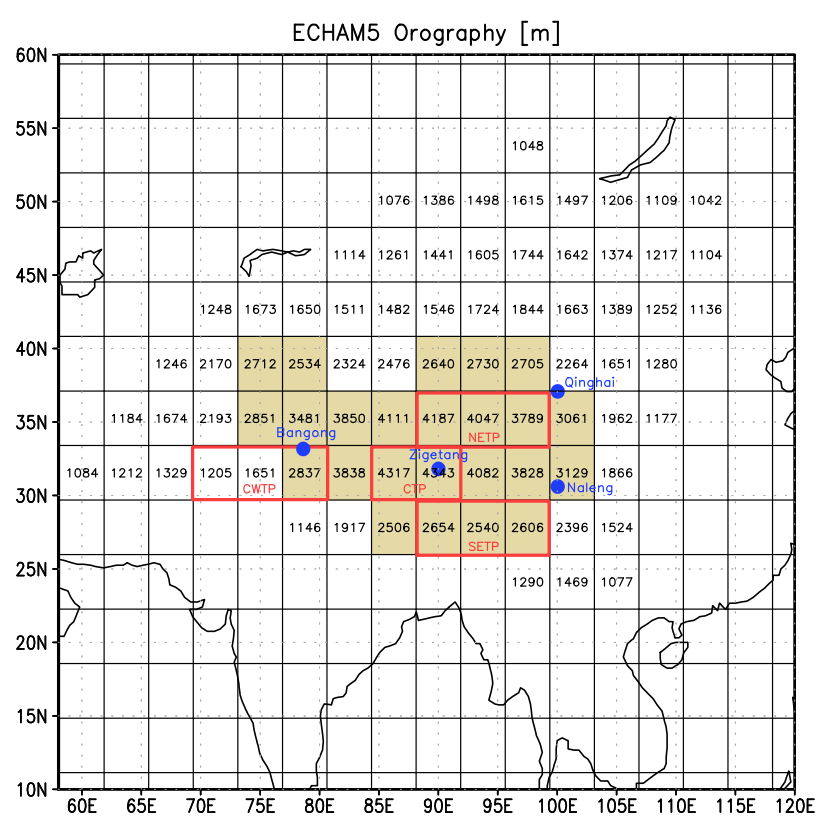

Fig. 2. ECHAM5 orography (elevation higher than $1000 \mathrm{~m}$ ), model grid (T31) and grid boxes used for determining the averaged vegetation trend in four different regions on the Tibetan Plateau (red boxes). These are the north-eastern Tibetan Plateau (NETP), the south-eastern Tibetan Plateau (SETP), the central Tibetan Plateau (CTP), and the central-western Tibetan Plateau (CWTP). The locations of lakes sampled for vegetation reconstructions are also shown (blue dots). Shaded area marks the regions on the Tibetan Plateau which are elevated above $2500 \mathrm{~m}$ in the model.

a single grid cell. The fractional cover of each PFT is determined by the balance of their establishment and mortality. The latter is the sum of the mortality by the aging of plants plus the disturbance-related mortality (fire and windbreak). The establishment is calculated from the relative differences in annual net primary productivity (NPP) between the PFTs, and hence includes the different moisture requirements of the plants. Furthermore, the establishment is weighted by the inverse of the PFT specific lifetime, i.e. plants that live long establish slowly. The establishment of woody PFTs is favoured over grass, so that grass can only establish in the area that is left after trees and shrubs have established. In the absence of disturbances, woody PFTs thus have an advantage over grasses, and the woody PFT with the highest NPP becomes the dominant vegetation-type in the grid-box. Generally, trees have the highest NPP since they have the largest leaf-area. However, in regions with frequent disturbances or in unfavourable climate conditions, i.e. bioclimatic conditions near the thresholds, shrubs or even grass might win the competition as they can recover more quickly than trees.

For each grid cell, a non-vegetated area is considered as well, which represents the fraction of seasonally bare soil and permanently bare ground. Their fraction is calculated via the relation of maximum carbon storage in the pool representing living tissues to the carbon actually stored in this pool. This approach is based on the fact that plants need a certain amount of carbon to build their leafs, fine roots, etc., so that they can function properly. If the model calculates a positive NPP for a vegetation type, carbon is filled into this pool, while carbon is lost from it proportional to the loss of leaves, which mostly happens in dry or cold seasons/periods. If the filling of the pool is not sufficient for all PFTs, plants cannot grow and the grid-cell is mainly non-vegetated.

Simulated changes in vegetation cover can thus be attributed to bioclimatic shifts (i.e. temperature changes), changes in plant productivity (related to precipitation), or changes in the frequency of disturbances. More details about the dynamic vegetation module are described in Brovkin et al. (2009).

In this study, PFTs are further aggregated to the three major vegetation types "forest" (containing all trees), "shrub", and "grass". The fourth land cover type "desert" includes the non-vegetated area. To test the significance of the simulated land cover trend, a simple statistical test is used. We 
assume a significant trend if the absolute differences in mean land cover between the first $500 \mathrm{yr}$ and the last $500 \mathrm{yr}$ is greater than two times the standard deviation of the entire time-series. Detailed results of this test can be seen in Appendix A (Table A1). According to this test, most land cover trends are significant. If a trend is not significant, this fact is mentioned in the text.

\subsection{Vegetation reconstruction}

The qualitative interpretation of pollen assemblages in terms of past vegetation (Birks and Birks, 1980) can be validated using a quantitative method for pollen-based biome reconstruction (biomisation, Prentice et al., 1996). Based on knowledge of the contemporary biogeography and ecology of modern plants, pollen taxa are assigned to plant functional types (PFTs) and the PFTs are assigned to main vegetation types (biomes). An affinity score for each biome is then calculated according to Prentice et al. (1996). The biome with the highest score dominates in the pollen-source area of the lake, while a relatively lower score indicates less occurrence of a biome in the area. Scores cannot be compared between different records. The pollen taxa-biome matrix (Table $\mathrm{C} 1$ ) applied in this study is based on the standard biomisation procedure presented by Yu et al. (1998) and their later improved version (Yu et al., 2000). A test of this method with a modern pollen data set of 112 lake sediment-derived pollen spectra from the Tibetan Plateau yielded a correct assignment of $100 \%$ of temperate desert sites, $75 \%$ of temperate steppe sites, $84 \%$ of alpine steppe sites, and $79 \%$ of alpine meadow sites (Herzschuh et al., 2010a). Patchy forest sites intermixed with alpine shrublands were mostly assigned to temperate or alpine steppes as no shrub biome was considered in this study. Here, we summarized the different biomes so that they fit best to the modelled vegetation types, namely forest, shrub, steppe/meadow and desert. The biome-taxa matrix is based on information on the distribution of the single pollen taxa with respect to vegetation types and biomes presented in Herzschuh and Birks (2010b and 2010c). The pollen-based reconstructions describe the vegetation trend qualitatively. The dominant vegetation type and the general trend can be inferred, but no conclusions on vegetation fraction and ratios can be made.

We are aware of differences in the handling of vegetation in the model and in the reconstructions. These differences have historical and technical reasons. Whereas the reconstructed vegetation is usually assigned to plant functional types (PFT) and then to biomes, simulated vegetation is grouped in plant functional types. These or the specific combinations of them then serve as major vegetation types. Nevertheless, we think it is most reasonable to compare pollenbased biomes with model-derived PFT coverages than to directly compare pollen-based PFTs with model-derived PFTs. The advantage of this method is particularly obvious in the case of model-proxy comparisons of deserts or of forested areas. The biome desert, for instance, contains vegetation such as Ephedra and Chenopodiaceae that can survive in extremely dry climatic conditions and are therefore representative for a desert environment and reach up to $100 \%$ here. In the model, no such vegetation type exists and the land cover type "desert" is only represented by the non-vegetated area (bare ground). Thus, to compare the pollen-based desert biome to the model bare ground (which also includes only seasonally bare ground) is most reasonable as the same bioclimate is assumed for these vegetations. In forest biomes, pollen-PFT-biome assignment also accounts for vegetation growing in the understorey such as herbs of Rubiaceae. Thus, vegetation cover can exceed $100 \%$ (due to more layers). In the model, vegetation competes for $100 \%$ of the grid-box and has to be arranged side by side, herbs (Grass PFT) only out-compete trees due to bioclimatic limitations.

\section{Results}

The reconstructed biome trends (forest, shrubland, steppe/meadow, desert) for all sites are illustrated in Fig. 3. Figure 4 shows the corresponding simulated vegetation trend as averages over $20 \mathrm{yr}$ which is the highest temporal resolution occurring in the reconstructions. Thereby, the simulated land cover is divided into forest, shrub and grass fraction as well as non-vegetated area, which is further referred to as desert. Simulated climate and vegetation changes are attributed to orbital forcing alone.

The pollen record of Lake Qinghai (north-eastern Tibetan Plateau) reveals a continuous decrease of forest cover since the mid-Holocene (6k) and an expansion of steppe/meadow vegetation. Whereas forests and steppe/meadow dominated the land-cover at $6 \mathrm{k}$, steppe/meadow is the prevalent biome at present-day $(0 \mathrm{k})$. Shrub vegetation, as well as desert vegetation, covers only small areas and does not show obvious trends through time. In line with the reconstructions of Qinghai Lake, the simulated vegetation trend on the north-eastern Tibetan Plateau (NETP) shows a continuous forest decline and an expansion of grassland during the last $6000 \mathrm{yr}$. Forest as the dominating land cover type during the mid-Holocene (approx. $38 \%$ of the area) is halved until present-day. Grass and shrub fractions increase by $67 \%$ and $64 \%$, covering $39 \%$ and $19 \%$ of the area at $0 \mathrm{k}$, respectively. Thus, grass is the prevalent vegetation simulated and reconstructed for the north-eastern Tibetan Plateau at present-day. The desert fraction slightly decreases from $27 \%$ at $6 \mathrm{k}$ to $23 \%$ at $0 \mathrm{k}$.

The pollen-based vegetation reconstruction from Lake Naleng (south-eastern Tibetan Plateau) suggests a qualitatively similar vegetation trend. During the mid-Holocene, steppe/meadow and forest were the dominant biomes. Around $4.3 \mathrm{k}$, forests started to retreat and were replaced by steppes and meadows. Thus, pollen abundances clearly reveal that steppe and meadow vegetation dominate in the area of Lake Naleng for present-day. Desert and shrub vegetation 

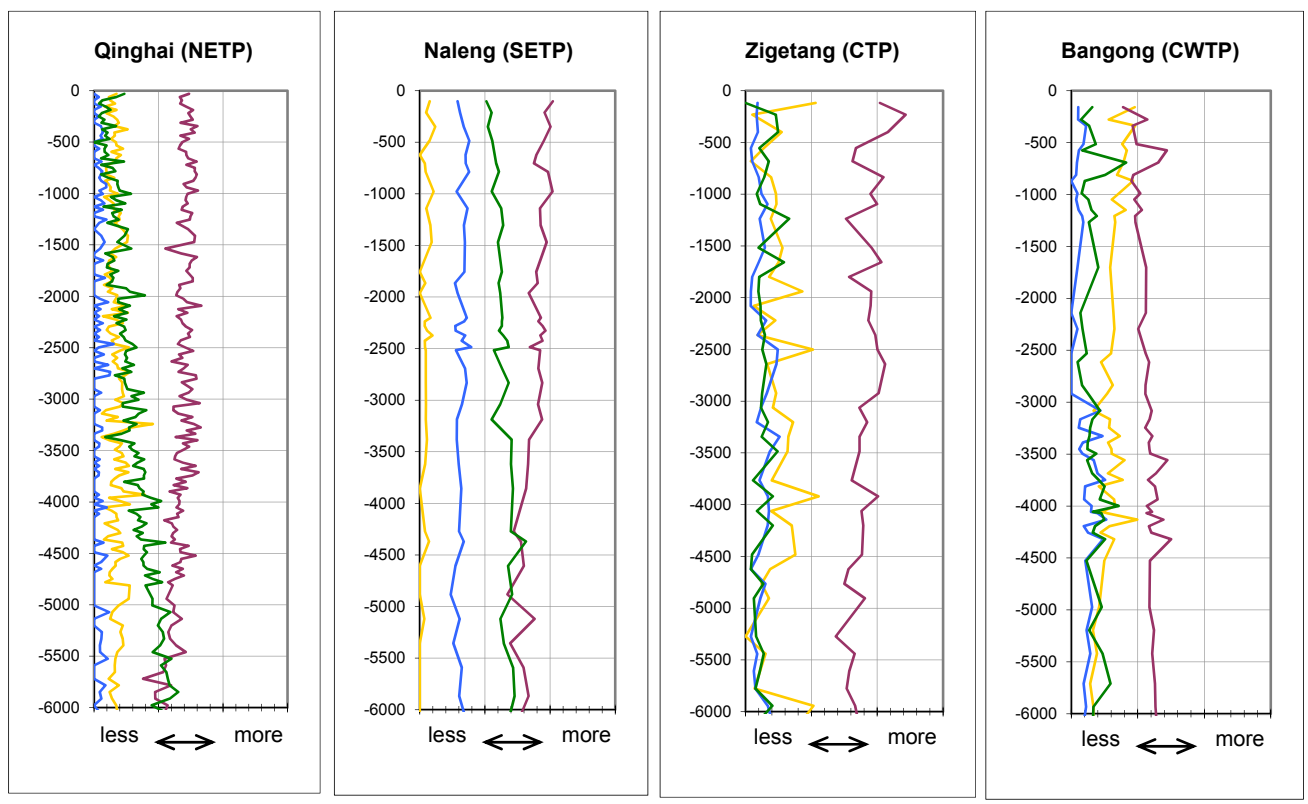

\section{desert $\longrightarrow$ steppe/meadow shrubs $\longrightarrow$ forest}

Fig. 3. Reconstructed vegetation trend from mid-Holocene (6000 yr before present) to present-day, based on four different lake sediment cores on the Tibetan Plateau (in arbitrary units).
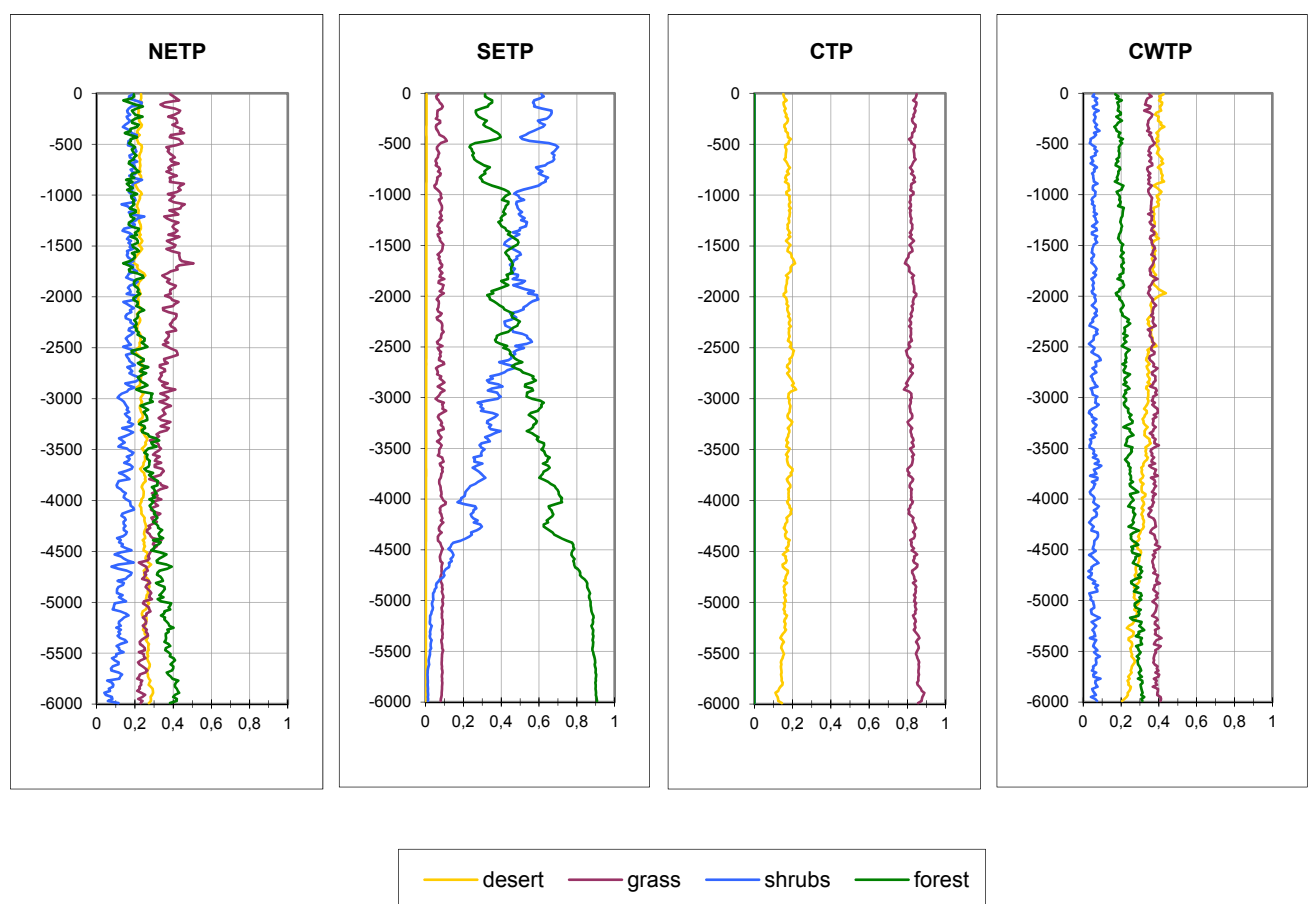

Fig. 4. Simulated vegetation trend ( $20 \mathrm{yr}$-mean) from mid-Holocene ( $6000 \mathrm{yr}$ before present) to present-day, averaged for 4 different regions on the Tibetan Plateau: the north-eastern Tibetan Plateau (NETP), the south-eastern Tibetan Plateau (SETP), the central Tibetan Plateau (CTP), and the central-western Tibetan Plateau (CWTP), see Fig. 2. Values are given in fraction per grid box. 
have stayed low constantly since $6 \mathrm{k}$. The simulated midHolocene land-cover on the south-eastern Tibetan Plateau (SETP) mainly consists of forest $(91 \%)$ and to a lesser extent of grass and shrubs ( $8 \%$ and $1 \%$, respectively). This vegetation distribution is constant for nearly $1200 \mathrm{yr}$ until shrubs successively replace forest. This decrease of forest fraction agrees with the reconstruction from Lake Naleng; but in the reconstructions, steppe/meadow and not shrub fraction increase. A strong fluctuation in the modelled vegetation trend indicates an occasionally recovering tree fraction. At $0 \mathrm{k}$, shrub is the dominant land cover type according to the model (61\% of the area), while forests form only $31 \%$ of the landscape. Desert $(0 \%)$ as well as grass fraction stays constant for the whole $6000 \mathrm{yr}$.

Lake Zigetang is situated on the high-altitude central Tibetan Plateau. At $6 \mathrm{k}$ as well as $0 \mathrm{k}$, the area is primarily covered by steppe/meadow vegetation. The reconstructed Holocene vegetation change is small, but exhibits a slight increase of steppe/meadow vegetation. The occurrence of desert is highly variable. Shrub and tree pollen taxa occur with low but steady abundances. In contrast to the pollen record, the model simulates no forests and no shrubs on the central Tibetan Plateau (CTP) for the last $6000 \mathrm{yr}$. Like in the reconstructions, grass covers most of the area at $6 \mathrm{k}(86 \%)$ as well as at $0 \mathrm{k}(85 \%)$. The simulated vegetation change is small and not significant. However, grassland slightly retreats during the first $3000 \mathrm{yr}$ (to $80 \%$ at $3 \mathrm{k}$ ) and increases again afterwards.

The pollen record of Lake Bangong from the western Tibetan Plateau depicts a regional reduction of vegetation during the last $6000 \mathrm{yr}$. Forest as well as steppe/meadow vegetation have decreased; desert indicating plants have spread since the mid-Holocene. Whereas steppe was the dominant biome at $6 \mathrm{k}$, pollen concentrations suggest land coverage of desert and steppe in equal parts for present-day. In agreement to the reconstructions from Lake Bangong, the model calculates an overall decrease of vegetated area on the centralwestern Tibet Plateau (CWTP). Whereas grass (41\%) and forest $(31 \%)$ characterise the landscape during the midHolocene, desert (42\%) dominates the region at present-day. Simulated forest fraction is nearly halved; desert fraction is more than doubled during the last $6000 \mathrm{yr}$. Shrub and grass only decrease by ca. $15 \%$, respectively, but the trend in shrub cover is not significant according to the simple statistical test used in this study.

Overall, the reconstructed and simulated vegetation trends are in agreement, albeit some systematic differences appear. The potential reasons for these differences are discussed in the following section.

\section{Discussion}

\subsection{Potential reasons for disagreements in the simulated and reconstructed vegetation cover}

The pollen-based vegetation reconstructions in this study may be influenced by the following factors:

1. Especially pollen spectra from large lakes such as Qinghai Lake contain a large extra-regional pollen component that increases with lake size (Jacobsen and Bradshaw, 1981) and strongly depends on regional atmospheric conditions (Gehrig and Peeters, 2000). Local pollen production and vegetation composition influence the concentration of long-distance transported pollen grains as well. Therefore, extra-regional pollen load may vary with time. Since the Tibetan Plateau exhibits a highly heterogeneous, often treeless environment with steep elevations and pronounced vegetation gradients, the problem of extra-regional pollen advection to the lakes is particularly large. The topography of the Tibetan Plateau can form strong anabatic winds transporting pollen from lower vegetation (forest) belts to steppe and desert zones (Markgraf, 1980; Cour et al., 1999; Kramer et al., 2010).

2. Pollen-productivity and hence its representation in the pollen record depends on the plant species. Most subalpine shrubs, for instance, are poor pollen-producers and thus have a low representation in pollen spectra (van Campo et al., 1996; Herzschuh and Birks, 2010). Hence, shrub coverage is most probably underestimated in our biome reconstructions.

3. Most pollen can only be identified to genus or family level. The assignment of pollen taxa to biomes within the biomisation techniques is therefore a strong simplification of the natural conditions. The most common biomes on the Tibetan Plateau, desert and steppe, share many pollen taxa even though the pollen producing plants belong to different species. Biomisation of fossil pollen assemblages from such non-forested areas often faces the problem of neighbouring samples being assigned to different biomes despite no obvious shifts in the pollen signal. This reflects ecological noise rather than a true biome shift because the assignment of the dominant biome is very sensitive to small variations of affinity scores between pairs of closely matched biomes such as desert, steppe, or meadow. We face this problem by presenting the affinity score differences between the most important biomes at each site.

The simulated vegetation trend is limited by the following factors:

1. Due to the coarse numerical resolution (T31L19), the orography is not represented well in the model. This 
especially applies to the Tibetan Plateau. Whereas its mean elevation exceeds $4000 \mathrm{~m}$ in reality, orography in the model reaches $4000 \mathrm{~m}$ at most and only in a few grid-boxes on the central Tibetan Plateau. The Himalaya and the Kunlun Mountains as well as other mountain ranges vanish. In reality, the strong spatial variance in orography (e.g. at Lake Naleng) implies a high heterogeneity of regional climate and vegetation, which cannot be captured in the model and may lead to discrepancies between the model results and reconstructions.

2. Compared to annual mean $2 \mathrm{~m}$-temperatures of European Centre for Medium-Range Weather Forecast Reanalysis (ERA40; Simmons and Gibson, 2000), simulated climate is too cold on the central and south-eastern Tibetan Plateau (up to $-2.8^{\circ} \mathrm{C}$ ) and too warm on the northern Tibetan Plateau (see Fig. 5). Maximal positive temperature anomalies of up to $7.2{ }^{\circ} \mathrm{C}$ occur on the north-western Tibetan Plateau. These differences between the model and reanalysis-data may partly arise from a lower (pre-industrial) greenhouse-gas concentration in the model. The comparison of the model output with observations (here: Global Precipitation Climatology Project (GPCP); Adler et al., 2003) also shows that the Asian summer monsoon intensity is overestimated in the central and southern regions of the Tibetan Plateau (see Fig. 5). Summer (JJA) precipitation anomalies reach values of up to ca. $7.5 \mathrm{~mm} \mathrm{day}^{-1}$. The simulated vegetation depends on certain climate thresholds, e.g. bioclimatic limiting factors. Therefore, biases in the calculated climate may lead to errors in the vegetation distribution and vegetation trend, particularly if the simulated local climate is near these thresholds, where sensitivity of land cover to climate change is expected to be large.

3. To avoid large climatic biases to observations, vegetation studies are often conducted by prescribing a biases-corrected climate (i.e. sum of simulated climate anomaly and observed mean climate) to a vegetation model instead of using a dynamically coupled atmosphere-ocean-vegetation model (e.g. Wohlfahrt et al., 2008; Miller et al., 2008). This anomaly-approach is particularly useful in climate impact studies but has the drawback of not taking feedbacks between the climate and vegetation into account. Previous climate modelling studies suggest that vegetation and land-surface feedbacks with the atmosphere could have enhanced the orbitally-induced Holocene climate change in monsoon regions (e.g. Claussen und Gayler, 1997; Broström et al., 1998, Diffenbaugh and Sloan, 2002; Levis et al., 2004; Li et al., 2009). In ECHAM5/JSBACH-MPIOM, the overall contribution of the vegetation-atmosphere interaction to the Holocene climate change in the Asian
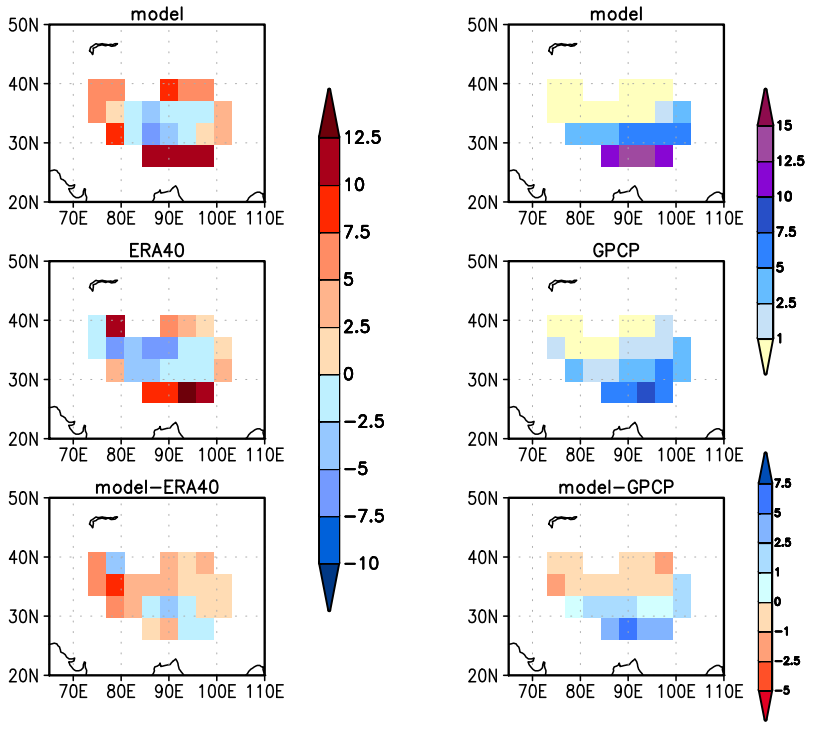

Fig. 5. Annual mean $2 \mathrm{~m}$-temperature in ${ }^{\circ} \mathrm{C}$ (left panel) and summer precipitation in $\mathrm{mm} \mathrm{day}^{-1}$ (right panel) calculated from the last $100 \mathrm{yr}$ of our coupled model experiment and a reference dataset. For temperature, results are compared with the reanalysis data ERA40 (Simmons and Gibson, 2000); for precipitation, observational data GPCP (Adler et al., 2003) is used. Shown are also differences between model results and the reference dataset.

monsoon region is small (Dallmeyer et al., 2010). However, in regions showing a strong land cover change (e.g. in parts of the Tibetan Plateau or the present-day monsoon margin), the Holocene vegetation change has a significant effect on the simulated climate. Therefore, we decided to use a coupled atmosphere-ocean-vegetation model in the current study to account for nonlinearities in the climate system, albeit this method may lead to biases in land cover trend.

4. Anthropogenic land cover change is another potential source of error as this cannot be depicted with our model configuration, but may be included in the reconstructions. Nomadic people may have influenced the midHolocene land-cover on the Tibetan Plateau, at least on lower elevations. The earliest Neolithic settlement on the south-eastern Tibetan Plateau took place at an age between $6.5 \mathrm{k}$ and $5.6 \mathrm{k}$ (Aldenderfer, 2007). Humans lived on the margin of the north-eastern Tibetan Plateau at least seasonally during the period $9 \mathrm{k}-5 \mathrm{k}$ (Rhode et al., 2007). The expansion of Neolithic cultures coincides well with the forest decline in regions north-east of the Tibetan Plateau (Aldenfelder and Zhang, 2004; Brantingham and Gao, 2006) and in China (e.g. Ren, 2000). To what extent humans influenced the Holocene vegetation change on the Tibetan Plateau is still a matter of discussion (Schlütz and Lehmkuhl, 2009; Herzschuh et al., 2010a). 


\subsection{Site-specific discussion of the vegetation change}

In the following, the indices "ann", "wm", and "cm" stand for annual, warmest month, and coldest month, respectively. The indices " $0 \mathrm{k}$ " and " $6 \mathrm{k}$ " denote the simulated present-day and mid-Holocene climate, respectively.

\subsubsection{North-eastern Tibetan Plateau}

The simulated present-day climate on the north-eastern Tibetan Plateau (NETP) is dry and cold. Annual mean precipitation $\left(p_{\mathrm{ann} 0 \mathrm{k}}\right)$ and temperature $\left(T_{\mathrm{ann} 0 \mathrm{k}}\right)$ are $230 \mathrm{~mm} \mathrm{yr}^{-1}$ and $-1.8^{\circ} \mathrm{C}$, respectively (Table 2 ). Thus, the calculated mean climate is in general agreement with observations around Lake Qinghai $\left(T_{\text {ann }}=-0.7{ }^{\circ} \mathrm{C}, p_{\text {ann }}=250 \mathrm{~mm} \mathrm{yr}^{-1}\right)$. Simulated temperatures range from $T_{\mathrm{cm} 0 \mathrm{k}}=-15.3{ }^{\circ} \mathrm{C}$ in the coldest month to $T_{\mathrm{wm} 0 \mathrm{k}}=9.3^{\circ} \mathrm{C}$ in the warmest month. Therefore, the only possible woody PFTs are cold shrubs and extratropical forests (cf. Fig. B5). At $6 \mathrm{k}$ as well as $0 \mathrm{k}$, the bioclimatic conditions of these PFTs are only partly fulfilled because the limit for the growing degree days above $5{ }^{\circ} \mathrm{C}$ is not always reached (Fig. 6). Due to the warmer summer season during the mid-Holocene $\left(T_{\mathrm{wm} 6 \mathrm{k}}=10.6^{\circ} \mathrm{C}\right)$ compared to present-day, trees can grow easier at that time. The extension of the growth phase as well as the higher amount of precipitation $\left(p_{\text {ann6k }}=290 \mathrm{~mm} \mathrm{yr}^{-1}\right)$ provide a more favourable climate for trees. The orbitally-induced gradual cooling towards present-day results in a decline of forest and an increase of grass.

The similarity between the simulated and reconstructed vegetation trend suggests a natural climate change (summer insolation) as the main driving factor for the decreasing forest fraction on the north-eastern Tibetan Plateau. The simulation confirms recent results of a rather minor role of human activity in forming the land cover change in the area (Herzschuh et al., 2010a). However, the model results clearly point out warm season temperatures (GDD5) as the controlling factor, whereas reconstructions identified monsoon intensity related precipitation changes as the primary explanation for the vegetation trend (Herzschuh et al., 2010a). Stable oxygen-isotope measurements performed on ostracod valves suggest a wetter climate during the early-Holocene (9k-6k), a strongly decreasing precipitation trend until $3 \mathrm{k}$, and rather stable conditions afterwards (X. Liu et al., 2007).

\subsubsection{South-eastern Tibetan Plateau}

Lake Naleng is located at an elevation of $4200 \mathrm{~m}$, whereas the mean orography prescribed to the model reaches only $2600 \mathrm{~m}$ in SETP (Table 2). Therefore, the simulated annual temperature and precipitation are highly overestimated $\left(p_{\mathrm{ann} 0 \mathrm{k}}=1850 \mathrm{~mm} \mathrm{yr}^{-1}, T_{\mathrm{ann} 0 \mathrm{k}}=11.1^{\circ} \mathrm{C}\right)$. Bioclimatic conditions $\left(T_{\mathrm{cm} 0 \mathrm{k}}=1.6^{\circ} \mathrm{C}, T_{\mathrm{wm} 0 \mathrm{k}}=17.3^{\circ} \mathrm{C}\right)$ support growing of raingreen shrubs and extratropical forests as the only possible woody PFTs (Fig. B6).
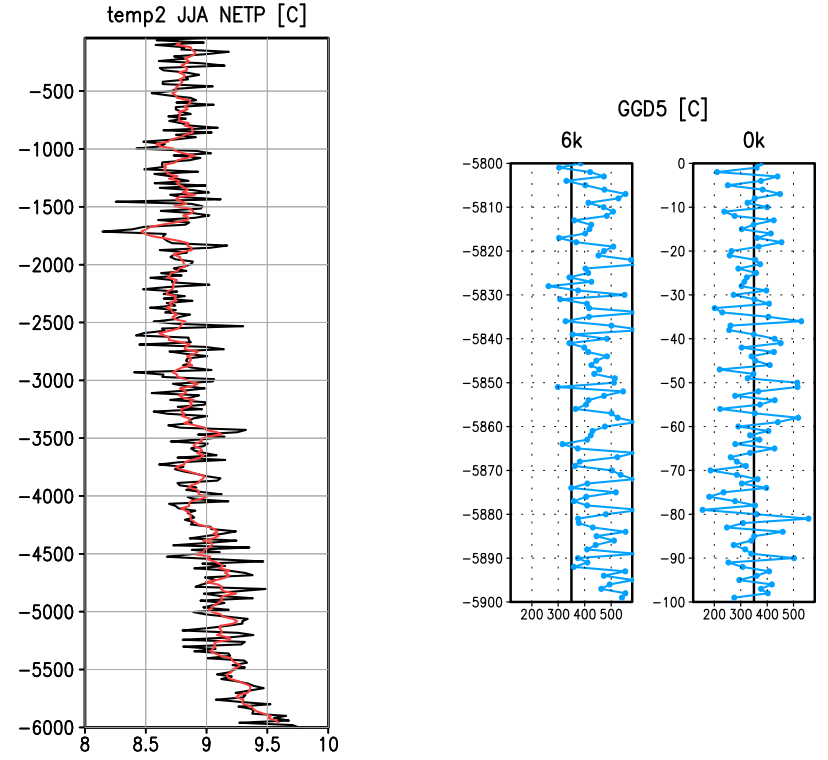

Fig. 6. Change of the climate factors yielding the land cover change on the north-eastern Tibetan Plateau (NETP), left panel: 20 yr-mean summer near-surface air temperature trend $\left[{ }^{\circ} \mathrm{C}\right]$ from mid-Holocene $(-6000 \mathrm{yr})$ to present-day. The red solid line shows the $100 \mathrm{yr}-$ running-mean. Right panel: difference in growing degree days between $100 \mathrm{yr}$ of the mid-Holocene $(-5900 \mathrm{yr}$ to $-5800 \mathrm{yr})$ and the last $100 \mathrm{yr}$ of the simulation period representing present-day. The solid black line marks the GDD5 threshold for extratropical forest of $350^{\circ} \mathrm{C}$.

In this area, the model simulates a higher NPP for raingreen shrubs than for extratropical trees (Fig. B6), so that the preferred land cover type would be shrubs. Due to less winter insolation at $6 \mathrm{k}$, the region experiences a colder winter climate than at present-day $\left(T_{\mathrm{cm} 6 \mathrm{k}}=0.8^{\circ} \mathrm{C}\right)$. Frost events occur regularly (see Fig. 7). Therefore, raingreen shrubs are excluded as mid-Holocene land cover due to less favourable bioclimatic conditions. With increasing winter insolation, the cold season becomes warmer and frost events rare. Given a higher NPP in the model, raingreen shrubs are then able to successively replace the evergreen trees. However, the vegetation cover fluctuates because frost events still occur with lower frequency.

Whereas the pollen reconstructions show an increase of steppe/meadow towards present-day, the model calculates shrubs as the forests-replacing land cover type. This difference in vegetation trend may partly result from the strong temperature bias of the model. The simulated annual mean temperature in SETP is nearly $10^{\circ} \mathrm{C}$ higher than observed and well above the freezing point. Given the observed annual mean temperature $\left(T_{\mathrm{ann}}=1.6^{\circ} \mathrm{C}\right)$, frost would still limit the occurrence of shrubs and growing of shrubs would probably have been impossible during the entire $6000 \mathrm{yr}$. Simulated present-day land cover would, then, primarily be forest. 
Table 2. Simulated present-day (mod) and observed orographic height $(H)$, annual mean temperature $\left(t_{\text {ann }}\right)$ and precipitation $\left(p_{\text {ann }}\right)$ at each site on the Tibetan Plateau.

\begin{tabular}{llrrrrrr}
\hline Site & Location & $\begin{array}{r}H_{\text {real }} \\
{[\mathrm{m} \mathrm{a.s.1]}}\end{array}$ & $\begin{array}{r}H_{\text {mod }} \\
{[\mathrm{m} \mathrm{a.s.1.]}}\end{array}$ & $\begin{array}{r}p_{\text {ann }} \\
{\left[\mathrm{mm} \mathrm{yr}^{-1}\right]}\end{array}$ & $\begin{array}{r}p_{\text {ann,mod }} \\
{\left[\mathrm{mm} \mathrm{yr}^{-1}\right]}\end{array}$ & $\begin{array}{r}t_{\text {ann }} \\
{\left[{ }^{\circ} \mathrm{C}\right]}\end{array}$ & $\begin{array}{r}t_{\text {ann,mod }} \\
{\left[{ }^{\circ} \mathrm{C}\right]}\end{array}$ \\
\hline Qinghai & $36.55^{\circ} \mathrm{N}, 100.1^{\circ} \mathrm{E}$ & 3200 & 4008 & 250 & 230 & -0.7 & -1.8 \\
Naleng & $31.1^{\circ} \mathrm{N}, 99.75^{\circ} \mathrm{E}$ & 4200 & 2600 & 630 & 1850 & 1.6 & 11.1 \\
Zigetang & $32^{\circ} \mathrm{N}, 90,9^{\circ} \mathrm{E}$ & 4500 & 4330 & $300-500$ & 743 & $-2.6--0.3$ & -4.8 \\
Bangong & $33.42^{\circ} \mathrm{N}, 79^{\circ} \mathrm{E}$ & 4200 & 1898 & 70 & 250 & -1.5 & 16.5 \\
\hline
\end{tabular}
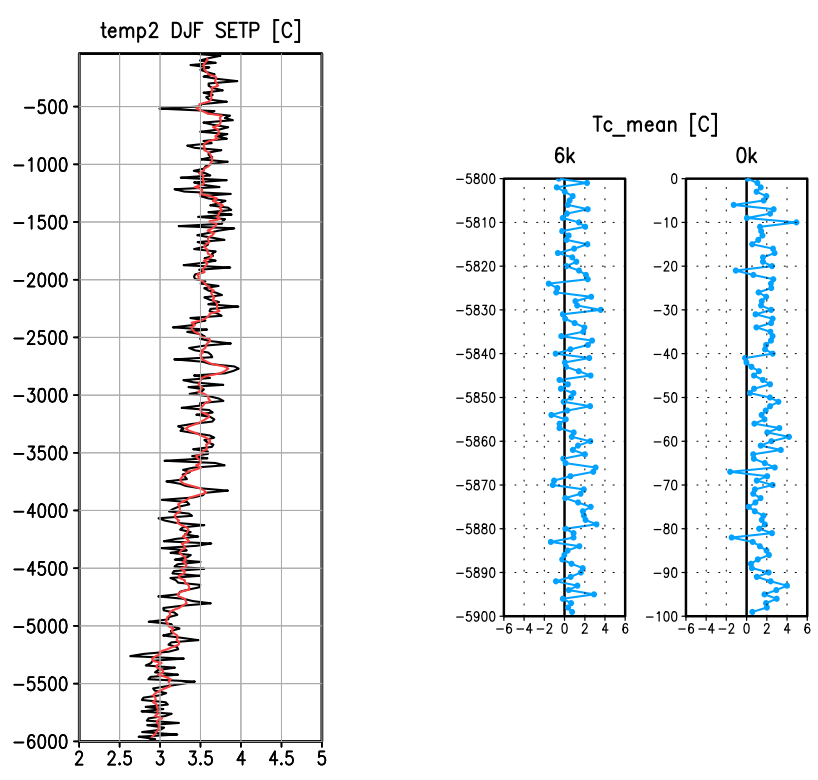

Fig. 7. Change of the climate factors yielding the land cover change on the south-eastern Tibetan Plateau (SETP), left panel: 20 yr-mean winter near-surface air temperature trend $\left[{ }^{\circ} \mathrm{C}\right]$ from mid-Holocene ( $-6000 \mathrm{yr}$ ) to present-day. Red solid line shows the $100 \mathrm{yr}$-runningmean. Right panel: difference in mean near-surface air-temperature of the coldest month between $100 \mathrm{yr}$ of the mid-Holocene $(-5900$ $\mathrm{yr}$ to $-5800 \mathrm{yr}$ ) and the last $100 \mathrm{yr}$ of the simulation period representing present-day. Raingreen shrubs are limited by frost events; the solid black line marks the freezing point $\left(0^{\circ} \mathrm{C}\right)$.

Furthermore, human activity cannot be excluded from having an influence on the vegetation trend and modern distribution. Grazing indicators suggest human impact on the environment around Lake Naleng since $3.4 \mathrm{k}$ (Kramer et al., 2010). Thus, forest clearance as well as fire activity and grazing may have contributed to the forest decline on the southeastern Tibetan Plateau (Schlütz and Lehmkuhl, 2009).

Pollen reconstructions assume decreasing summer temperatures as the major controlling climate factor, causing a downward shift of the treeline (Kramer et al., 2010). As Lake Naleng is situated in an area where forests gradually pass into subalpine shrub and alpine meadow, a transition from forest to shrubland during the Holocene would have been possible as well. Since shrub genera in that area, such as Potentilla, Caragana, Spiraea, Rhododendron, are poor pollen producers, shrubby vegetation may be underestimated in the vegetation reconstruction from Lake Naleng pollen spectra.

However, winter temperature is the main driving climate factor for the vegetation trend in the model. With regard to the discrepancy in local climate, the simulated vegetation trend should be interpreted in a broader sense: during the mid-Holocene, colder winters provided more unfavourable climatic conditions for frost-sensitive plants than at presentday. With increasing winter temperatures, they might have had a chance to establish in spite of the pressure of other competitive, frost-resistant plants.

\subsubsection{Central Tibetan Plateau}

The simulated climate on the central Tibetan Plateau is cold and relatively wet. Annual mean precipitation is overestimated by the model (Table 2); it reaches $743 \mathrm{~mm} \mathrm{yr}^{-1}$, mainly provided by the Indian summer monsoon. With annual mean temperatures well below freezing point $\left(T_{\mathrm{ann} 0 \mathrm{k}}=\right.$ $-4.8^{\circ} \mathrm{C}$ ), climate conditions are too cold to allow the establishment of woody PFTs (Fig. B7). Even in the warm season, mean temperatures do not exceed $4.5^{\circ} \mathrm{C}$. Therefore, the annual temperature sum is not high enough to exceed the bioclimatic limit of growing degree days needed to get woody vegetation in the model.

These climate conditions have not changed much during the $6000 \mathrm{yr}$ of simulation. The calculated vegetation trend seems to follow the mean summer (JJA) temperature (Fig. 8). Lower temperatures around $3 \mathrm{k}$ yield a slight decrease of the grass fraction, indicating warm season temperatures as the controlling climate factor for the vegetation trend.

While the model simulates no forest and shrub on the central Tibetan Plateau, reconstructions for Lake Zigetang reveal at least a low pollen contribution from these vegetation types. These pollen grains represent low-elevation vegetation and have apparently been transported from far regions by the atmospheric wind circulation. This extra-regional pollen component is slightly higher during the late Holocene, when the regional vegetation is characterized by more openness as 

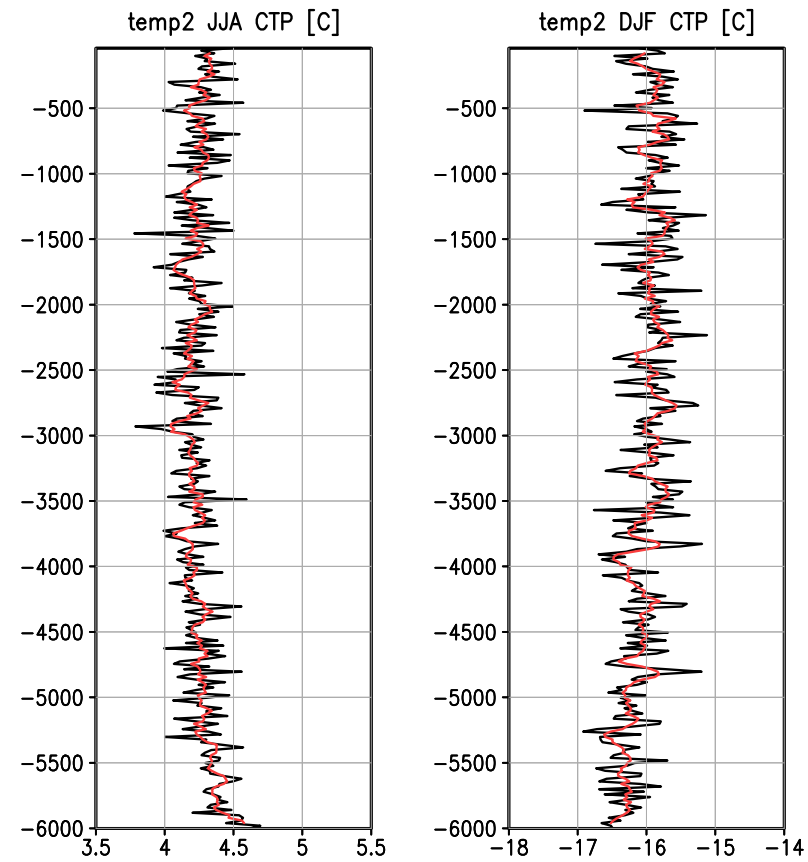

Fig. 8. Simulated change of summer (JJA) and winter (DJF) 20 yr-mean near-surface air temperature $\left[{ }^{\circ} \mathrm{C}\right]$ for the last $6000 \mathrm{yr}$ on the central Tibetan Plateau (CTP). The red solid line shows the 100 yr-running-mean.

indicated by the increase ruderal and desert plants such as Brassicaceae.

Pollen reconstructions suggest a vegetation transition from Artemisia-dominated alpine steppe at $6 \mathrm{k}$ to Kobresiadominated meadow at $0 \mathrm{k}$ (Herzschuh et al., 2006, 2010a) that was interpreted in terms of temperature decrease.

\subsubsection{Central-western Tibetan Plateau}

The simulated vegetation trend agrees well with the reconstructions from Lake Bangong, although the calculated climate highly differs from climate observations in the surrounding areas of this lake (Table 2). Due to the flat orography in the model (mean height $<2000 \mathrm{~m}$ ), simulated mean annual temperatures for present-day are $16.5^{\circ} \mathrm{C}$ instead of the observed $-1.5^{\circ} \mathrm{C}$. Moreover, the Indian monsoon intensity is slightly overestimated in that region. Annual mean precipitation reaches $250 \mathrm{~mm} \mathrm{yr}^{-1}$ (observed: ca. $\left.70 \mathrm{~mm} \mathrm{yr}^{-1}\right)$. Bioclimatic conditions $\left(T_{\mathrm{cm} 0 \mathrm{k}}=0.32^{\circ} \mathrm{C}\right.$, $T_{\mathrm{wm} 0 \mathrm{k}}=26.6^{\circ} \mathrm{C}$ ) support growth of extratropical forests and partly of raingreen shrubs (Fig. B8). The latter are hindered by the occasional occurrence of frosts. However, due to its location at the southern margin of the Plateau and due to the low regional pollen productivity, the pollen source area of the lake may comprise large areas of lower elevations and is thus rather similar to the modelled vegetation for that region.
Reconstructions as well as the model results identify precipitation - being mainly a function of the Indian monsoon strength - as the main driver for the vegetation change. Calculated annual mean precipitation is halved between $6 \mathrm{k}$ $\left(p_{\text {ann6k }}=500 \mathrm{~mm} \mathrm{yr}^{-1}\right)$ and $0 \mathrm{k}$ (see Fig. 9), resulting in an increase of desert fraction. Proxy data suggests a maximum of moisture availability between $7.2-6.5 \mathrm{k}$ and then a trend towards aridity (van Campo et al., 1996). Thus, climate reconstructions and model data both show a decrease of summer monsoon intensity on the western Tibetan Plateau during the last $6000 \mathrm{yr}$.

\subsection{Simulated total vegetation and biomass changes on the Tibetan Plateau}

Due to the underestimated orography in the model, the simulated fraction of potential vegetation cover on the Tibetan Plateau is probably overestimated and, therefore, not comparable with the present-day observed, anthropogenic effected distributions. However, as we are not aware of other modelling studies concerning the Holocene land cover change on the Tibetan Plateau, we use our model simulation to assess the total Holocene vegetation and biomass change in this region.

Table 3 illustrates the averaged simulated vegetation and biomass change on the Tibetan Plateau, which we ad hoc defined as those grid-boxes exceeding orographic height of $2500 \mathrm{~m}$ in the model (cf. Fig. 2). This area has a size of approx. 3.43 million $\mathrm{km}^{2}$.

Overall, the simulated forest fraction decreases by nearly one third, i.e. an area of ca. 0.45 million $\mathrm{km}^{2}$. Whereas forest covers approx. $41.4 \%$ of the Tibetan Plateau at midHolocene, only $28.3 \%$ area are covered by forests at presentday. Most of the forest has been replaced by shrubs, whose fraction is nearly four times larger at $0 \mathrm{k}(12.3 \%$ of the total area) than at $6 \mathrm{k}$ (ca. $3.2 \%$ of the total area). The area covered by grass increases from approx. $38.1 \%$ at mid-Holocene to $42.3 \%$ at present-day. Altogether, a small fraction of the Tibetan Plateau is more vegetated at present-day. Nonvegetated area is reduced from $17.29 \%$ at $6 \mathrm{k}$ to $17.16 \%$ at $0 \mathrm{k}$.

This vegetation change results in a relocation of carbon stored in the soil and plants. At mid-Holocene, approx. $2.8 \mathrm{kgC} \mathrm{m}^{-2}$ are stored in the vegetation, particularly in forests $\left(2.7 \mathrm{kgC} \mathrm{m}^{-2}\right)$. Due to the forest decline from $6 \mathrm{k}$ to $0 \mathrm{k}$, more than $1 \mathrm{kgC} \mathrm{m}^{-2}$ living biomass is released. Only half of this biomass loss is compensated by shrubs and, to a small extent, by grass. Therefore, the total living biomass loss on the Tibetan Plateau during the last $6000 \mathrm{yr}$ adds up to ca. $0.62 \mathrm{kgC} \mathrm{m}^{-2}$, on average. The Holocene climate change from $6 \mathrm{k}$ to $0 \mathrm{k}$ and the associated degradation of vegetation thus lead to a plant carbon loss of nearly one quarter.

The vegetation change on the Tibetan Plateau also strongly affects the total terrestrial biomass, i.e. the biomass stored not only in plants but also in soil and litter. In mid-Holocene, 
Table 3. Total vegetation and biomass change on the Tibetan Plateau between mid-Holocene ( $6 \mathrm{k})$ and present-day ( $0 \mathrm{k})$, averaged over all grid-cells with orography exceeding $2500 \mathrm{~m}$ in the model (see Fig. 2). Listed are the area covered by the vegetation types and by vegetation in total (fraction of grid-cell in \%), as well as living biomass, litter biomass, biomass allocated in the soil under the vegetation, and total biomass. Biomass is given in $\mathrm{gC} \mathrm{m}^{-2}$.

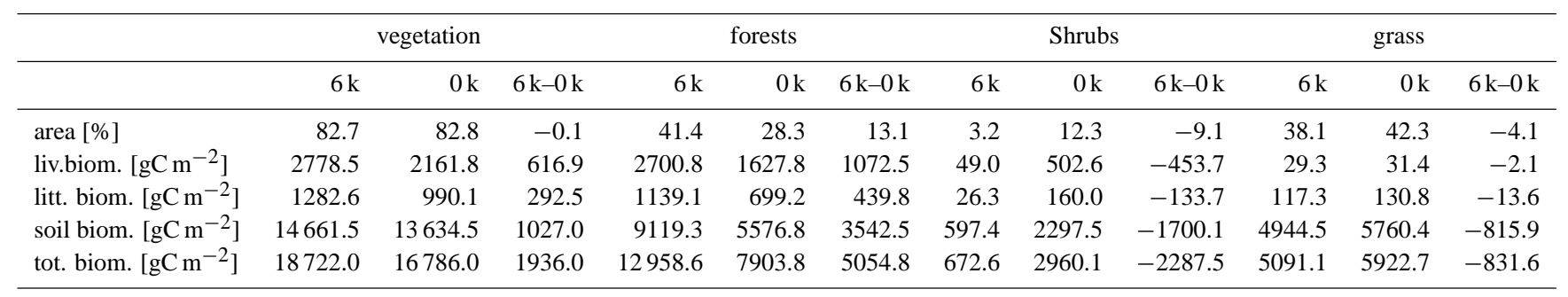

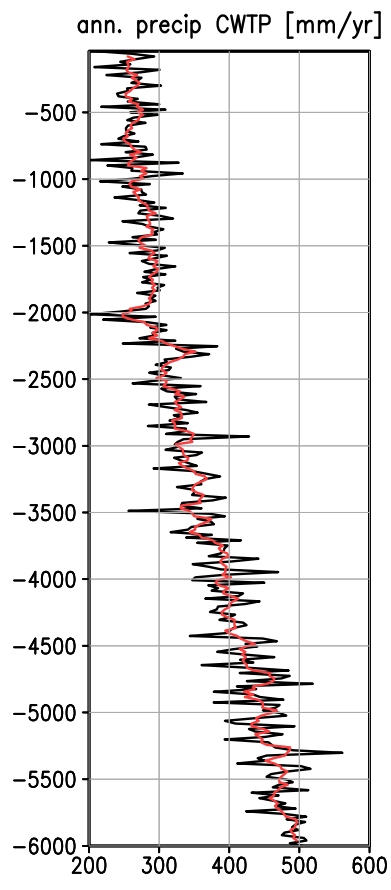

Fig. 9. Simulated change of 20 yr-mean annual precipitation $\left[\mathrm{mm} \mathrm{yr}^{-1}\right]$ for the last $6000 \mathrm{yr}$ on the central-western Tibetan Plateau (CWTP). The red solid line shows the 100 yr-running-mean.

approx. $18.7 \mathrm{kgC} \mathrm{m}^{-2}$ are fixed as terrestrial biomass. The reduction of area covered by forest yield a decrease of terrestrial carbon by more than $5 \mathrm{kgC} \mathrm{m}^{-2}$. Forest-replacing shrubs and grassland can partly compensate this biomass loss. Nevertheless, the total terrestrial carbon loss on the Tibetan Plateau between the mid-Holocene and present-day exceeds $1.9 \mathrm{kgC} \mathrm{m}^{-2}$ on average. Projected on the total area of ca. 3.43 million $\mathrm{km}^{2}$ (in the model), the terrestrial carbon loss adds up to $6.64 \mathrm{GtC}$. These are approx. $7.5 \%$ of the simulated global terrestrial biomass loss during the Holocene.

\section{Summary and conclusion}

Pollen-inferred vegetation trends on the Tibetan Plateau since the mid-Holocene were compared to simulated land cover changes conducted in a coupled atmosphere-oceanvegetation model with orbital forcing only. As the Tibetan Plateau exhibits diverse environmental and climate conditions, four different pollen records representing different parts of the Tibetan Plateau were considered. Causes of the vegetation change and consequences for the biomass storage have been investigated.

In general, the simulated and reconstructed vegetation trends are in agreement for most sites but reveal differences with respect to their climatic causes. The results of both methods indicate a degradation of the vegetation, particularly characterised by a strong decrease of forests. Simulated forest fraction is reduced by nearly one-third at presentday. Simulated total biomass on the Tibetan Plateau has decreased by ca. $6.64 \mathrm{GtC}$ since the mid-Holocene. In some cases, however, model and reconstructions attribute this vegetation change to different climatic factors, which partly results from the fact that both methods have their deficiencies. On the one hand, reconstructions might be affected by long-distance transports of pollen and the dependence of the pollen-production on the vegetation type and environmental conditions, including climate (Gaillard et al., 2010). Human influence can probably not be neglected either. On the other hand, the coarse resolution of the model and the associated underestimation of the orography lead to discrepancies between the simulated present-day climate and observation.

On the north-eastern Plateau (Lake Qinghai, NETP), the model reveals orbitally-induced cooling of the warm season as the responsible climatic factor for the forest decline. Reconstructions, however, suggest the reduction of summer monsoon precipitation as the limiting factor. The model results might indicate that, so far, the influence of temperature changes on the Tibetan Plateau vegetation has been underestimated as an explanation for the decreasing forest in paleoreconstructions for monsoon-affected areas. 
The vegetation degradation around Lake Naleng (SETP) is probably caused by changes in temperature between midHolocene and present-day. According to reconstructions, decreasing summer temperatures lead to a downward shift of the treeline and therefore to less forest vegetation around Lake Naleng (Kramer et al., 2010). The reduction of forest fraction in the model can be attributed to increasing winter temperature. Since the simulated climate for SETP strongly deviate from observation, this result should be interpreted with caution.

Harsh climatic conditions on the central Tibetan Plateau (Lake Zigetang) during the mid-Holocene as well as presentday lead to only slight vegetation changes in the model and in reconstructions.

The land cover degradation on the central-western Tibetan Plateau (Lake Bangong) can be attributed to a change in precipitation. Since the local climate is dry, the reduction of summer monsoon precipitation from $6 \mathrm{k}$ to $0 \mathrm{k}$ causes an expansion of deserts and a dieback of vegetation in the model as well as in reconstructions.

Although the spatial resolution of the model is coarse and the experimental set-up is designed to analyse climate and vegetation changes due to orbital forcing alone, the model results agree with the reconstructed vegetation trend on the Tibetan Plateau.

Therefore, reconstructed large-scale land cover change since the mid-Holocene can likely be attributed to natural and not anthropogenic reasons, although humans might still have strongly influenced the vegetation on a local scale. The comprehensive Earth system model used in this study captures the regional climatic reasons for the vegetation change in most instances. Thus, it provides a good tool to understand the long-term vegetation change on the Tibetan Plateau as well as its causes and consequences.

However, the discrepancy between the simulated climate and observations in some parts of the Plateau show that the analysis-options are limited in simulations with coarse spatial resolution. Detailed analyses of important processes such as local changes of the energy balance or atmospheric flow are only possible in experiments with higher numerical resolution, where the complex terrain of the Tibetan Plateau is represented better.

\section{Appendix A}

\section{Significance-test of the simulated vegetation trend}

To test the significance of the simulated vegetation trends, we applied a simple statistical test: we calculated the standard deviation of the time-series $(\sigma)$ and the difference between the mean value of the first $500 \mathrm{yr}$ and the last $500 \mathrm{yr}$ of the time-series ( $\Delta$ cov_frac). We assume a significant land cover trend, if $\mid \Delta$ cov_frac $_{-} \mid>2 \cdot \sigma$.
Table A1. Simple statistical significance test of the simulated land cover trend at each area on the Tibetan Plateau. $\sigma$ : standard deviation of the entire time-series, $\Delta \operatorname{cov}_{-}$frac: difference between the mean land cover of the first $500 \mathrm{yr}$ and last $500 \mathrm{yr}$ of the time-series.

\begin{tabular}{|c|c|c|c|c|}
\hline & desert & grass & shrubs & forest \\
\hline \multicolumn{5}{|c|}{ North Eastern Tibetan Plateau } \\
\hline $2 * \sigma$ & 0.040 & 0.132 & 0.073 & 0.148 \\
\hline$\Delta$ cov_frac & -0.052 & 0.175 & 0.087 & -0.210 \\
\hline \multicolumn{5}{|c|}{ South Eastern Tibetan Plateau } \\
\hline $2 * \sigma$ & 0.003 & 0.024 & 0.420 & 0.410 \\
\hline$\Delta \operatorname{cov}$ frac & 0.004 & -0.014 & 0.585 & -0.575 \\
\hline \multicolumn{5}{|c|}{ Central Tibetan Plateau } \\
\hline $2 * \sigma$ & 0.034 & 0.034 & 0.000 & 0.000 \\
\hline$\Delta \operatorname{cov}$ frac & 0.028 & -0.028 & 0.000 & 0.000 \\
\hline \multicolumn{5}{|c|}{ Central Western Tibetan Plateau } \\
\hline $2 * \sigma$ & 0.106 & 0.033 & 0.026 & 0.084 \\
\hline$\Delta$ cov_frac & 0.156 & -0.038 & -0.003 & -0.115 \\
\hline
\end{tabular}

Results of this test can be seen in Table A1. According to this test, the simulated land cover trend on the northeastern Tibetan Plateau is significant. For the south-eastern Tibetan Plateau, only the simulated grass cover shows a nonsignificant trend. The simulated land cover change on the central Tibetan Plateau has no trend. On the central-western Tibetan Plateau, the shrub cover trend is not significant but the desert, grass, and forest fraction show a significant trend.

\section{Appendix B}

\section{Summary of the simulated climate and land cover change on the Tibetan Plateau}

The simulated change in summer and winter temperature as well as the change in annual precipitation at each site of the Tibetan Plateau is shown in Figs. B1-B4. In all regions, the model calculates a decreasing Holocene precipitation trend that is probably related to the generally weakening of the Asian summer monsoon since the early- and mid-Holocene reported also in vegetation-independent reconstructions such as cave records (e.g. Fleitmann, 2003; Wang et al., 2005; Maher, 2008). Due to the increasing solar radiation in the Northern Hemisphere during winter, the simulated near-surface air temperature increases from mid-Holocene to present-day at all sites. Summer temperatures show a decreasing Holocene trend on the north-eastern Tibetan Plateau and an increasing trend on the south-eastern and central-western Tibetan Plateau. The differences in temperature trend can probably 


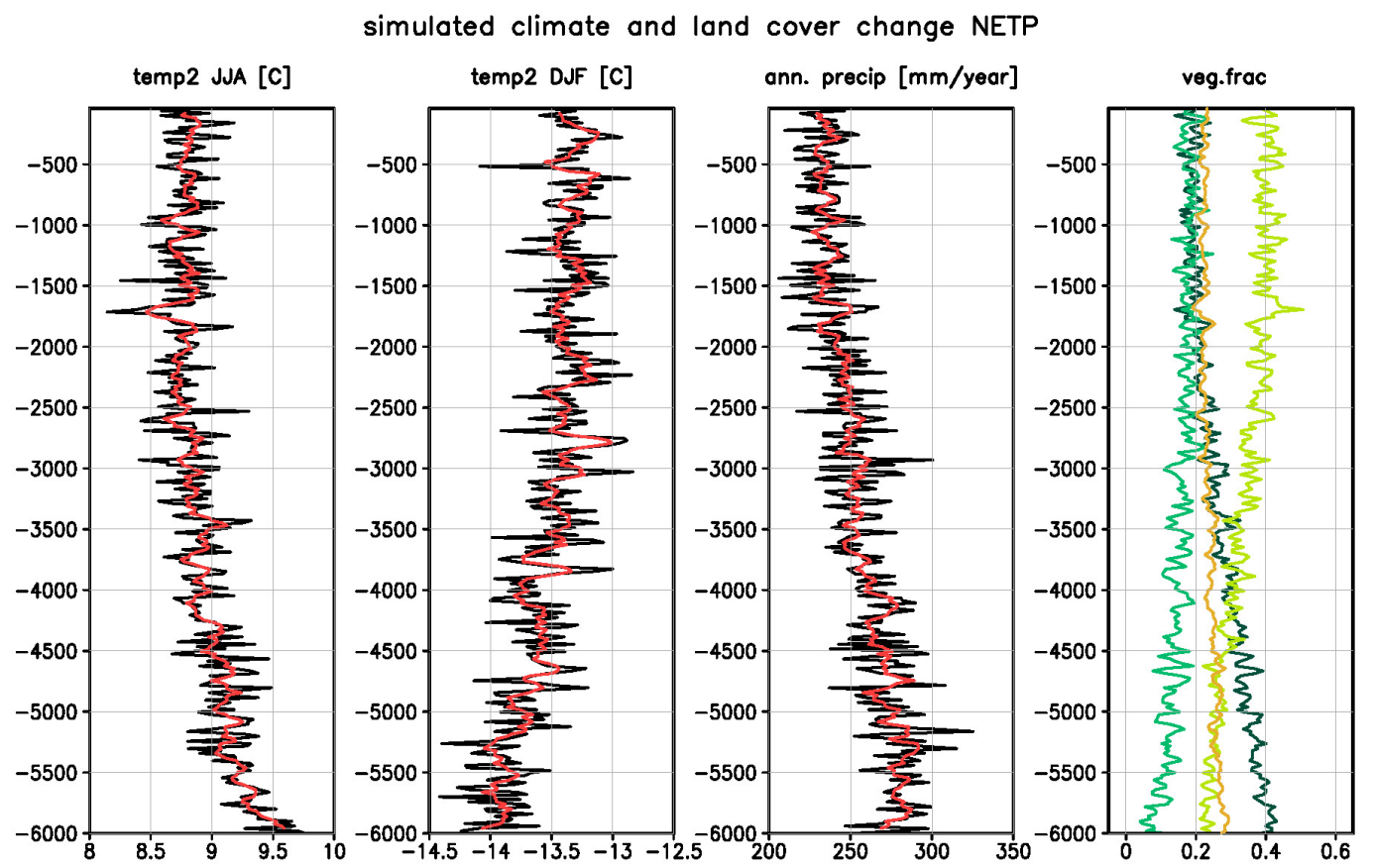

Fig. B1. Simulated change in summer (JJA) and winter (DJF) temperature $\left[{ }^{\circ} \mathrm{C}\right]$, annual precipitation $\left[\mathrm{mm} \mathrm{yr}^{-1}\right]$ and land cover $[$ fraction per grid-box] on the north-eastern Tibetan Plateau (NETP). Values are averaged over $20 \mathrm{yr}$, covering the last $6000 \mathrm{yr}$ from mid-Holocene to present-day. The red solid line shows the 100 yr-running-mean. Land cover is divided into forest (dark green), shrubs (green), grass (light green), and non-vegetated area (orange).

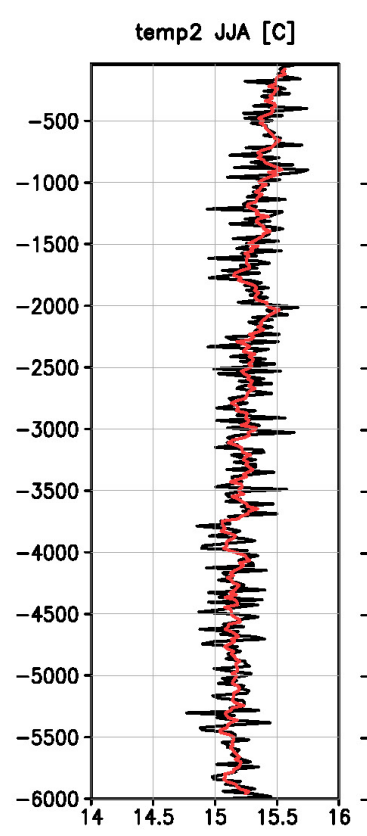

simulated climate and land cover change SETP
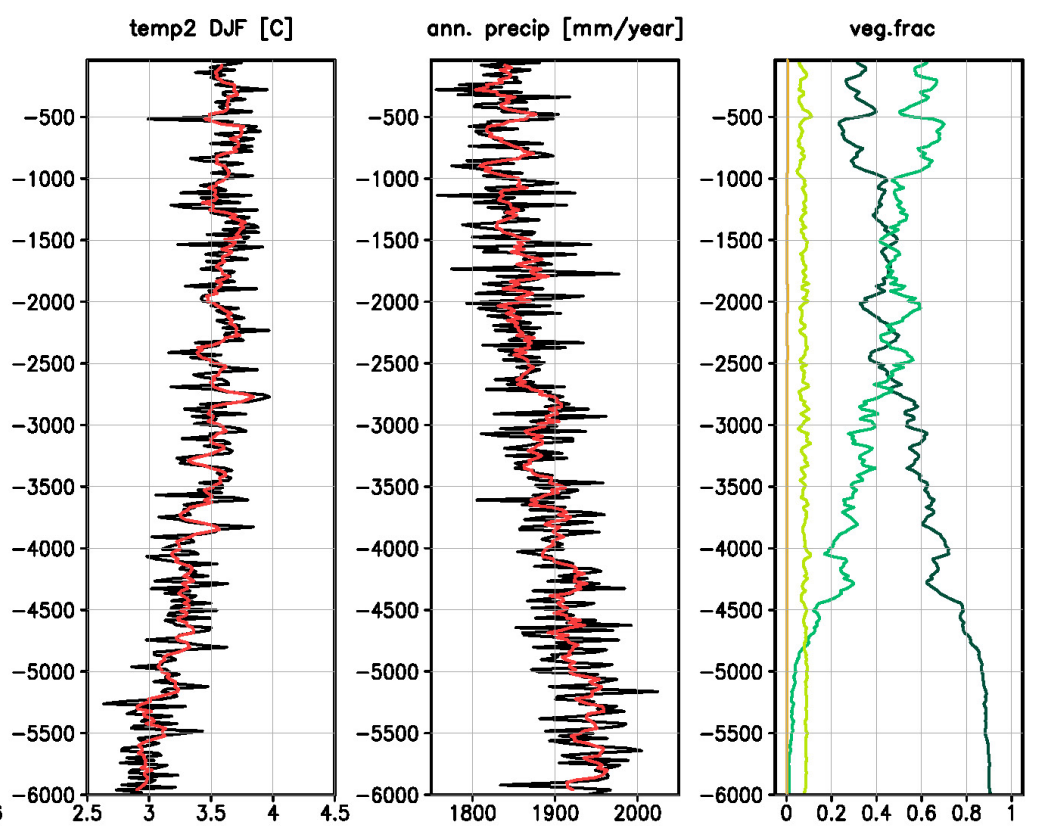

Fig. B2. Same as Fig. B1, but for the south-eastern Tibetan Plateau (SETP). 


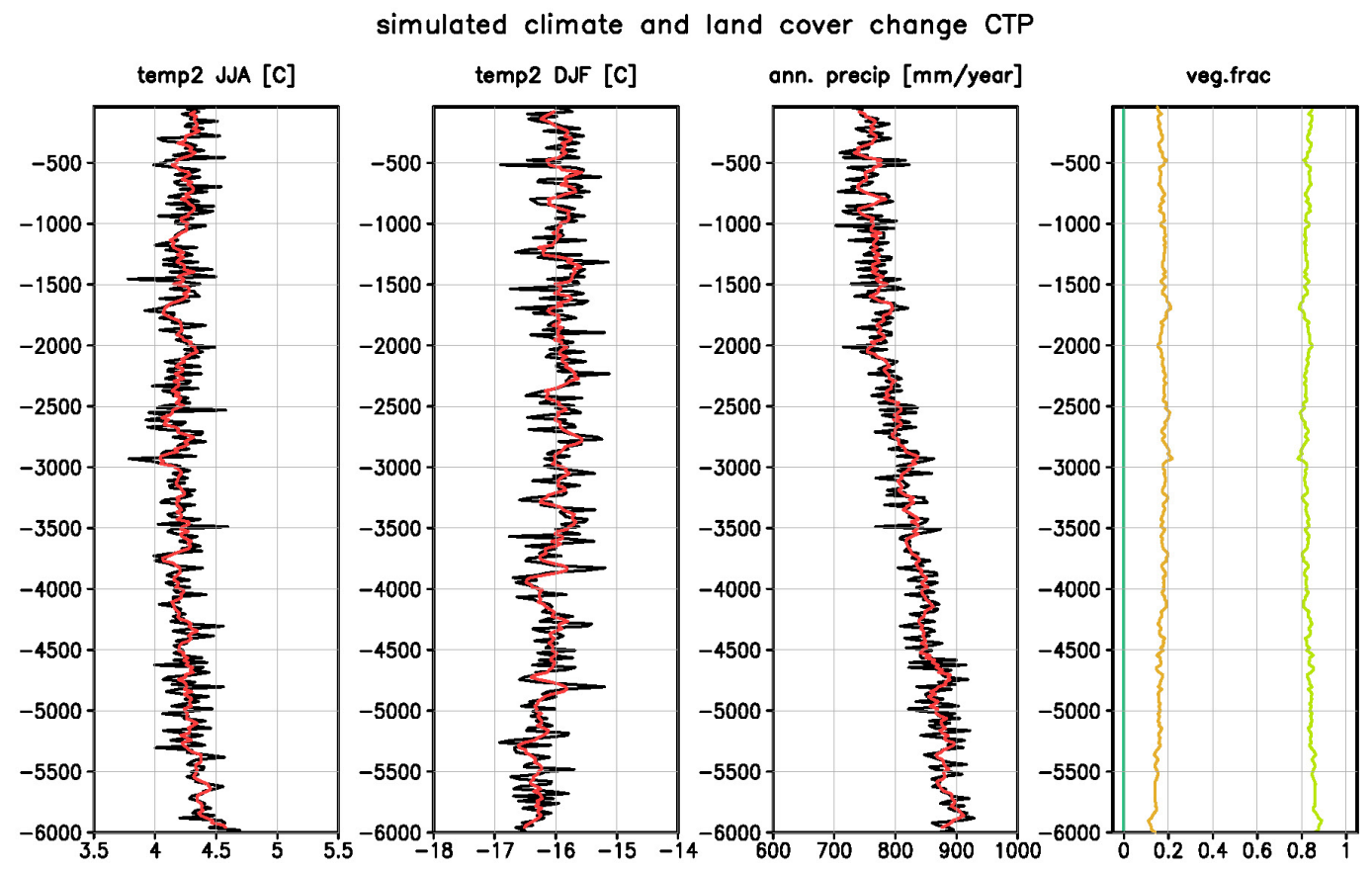

Fig. B3. Same as Fig. B1, but for the central Tibetan Plateau (CTP).

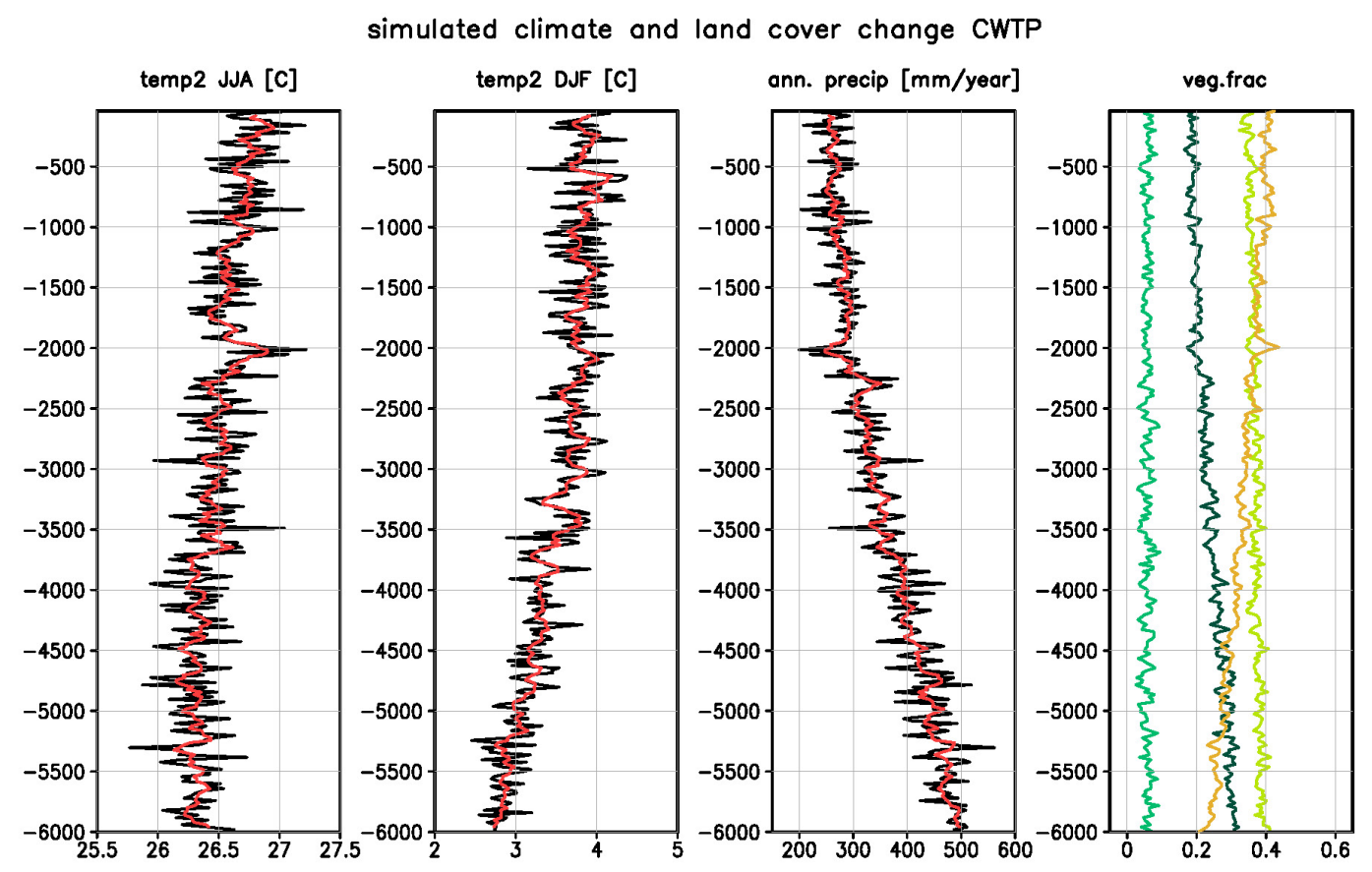

Fig. B4. Same as Fig. B1, but for the central-western Tibetan Plateau (CWTP). 

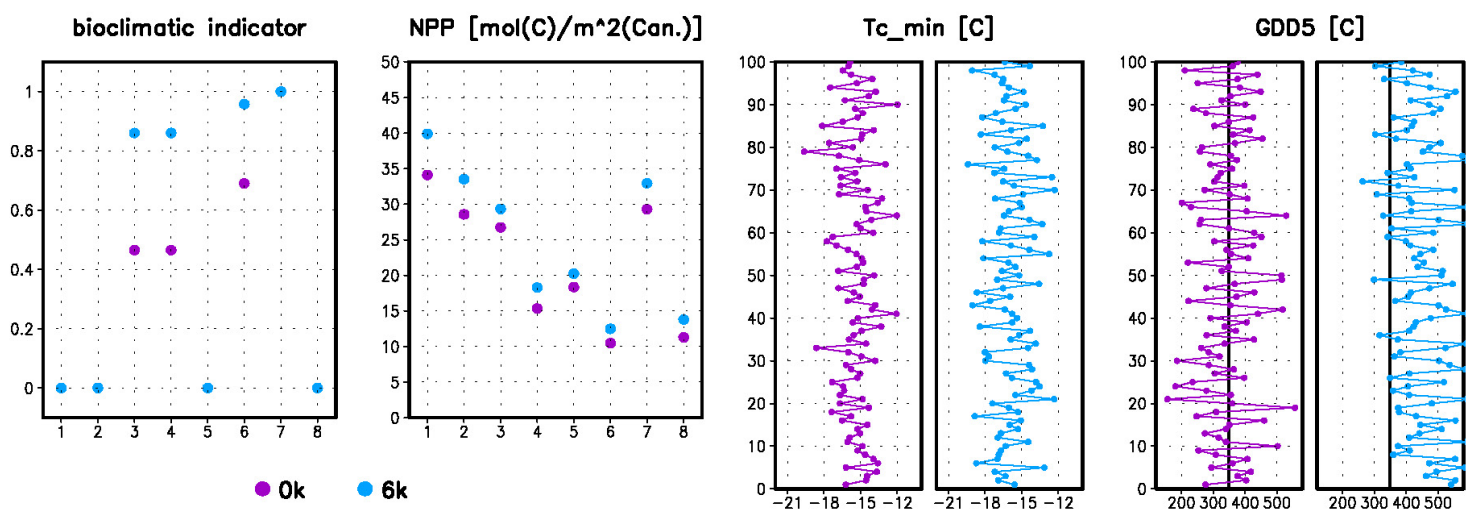

Fig. B5. Simulated change in bioclimatic conditions and the net primary productivity (NPP) on the north-eastern Tibetan Plateau for all simulated plant functional types (PFT, see Table 1). These are: tropical evergreen trees (1), tropical deciduous trees (2), extratropical evergreen trees (3), extratropical deciduous trees (4), raingreen shrubs (5), cold shrubs (6), C3 grass (7), and C4 grass (8). The bioclimatic indicator ranges from 0 (climate unfavourable) to 1 (climate favourable) and indicates if the bioclimatic conditions allow the establishment of the PFT. The lowest mean temperature of the coldest month $\left(\mathrm{Tc}_{\mathrm{min}}\right)$ and the growing degree days (GDD5) are based on the first and last $100 \mathrm{yr}$ of the transient simulation, representing the mid-Holocene and present-day climate, respectively. Black lines mark the nearest threshold (here: GDD5=350, limit for extratropical trees).
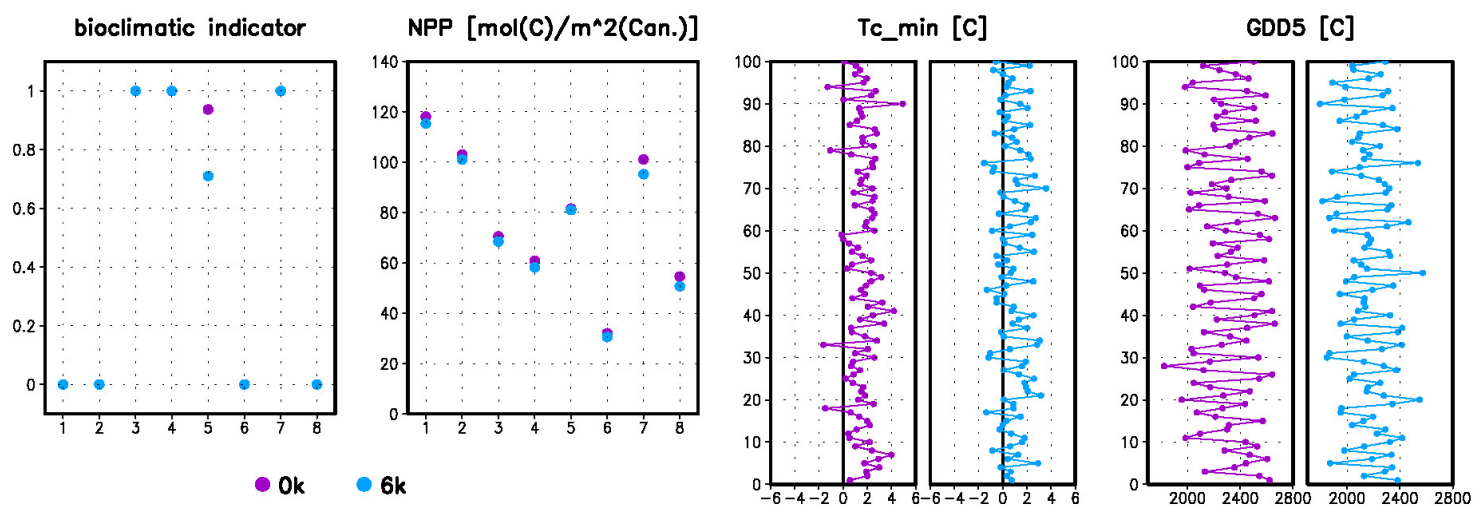

Fig. B6. Same as Fig. B5, but for the south-eastern Tibetan Plateau.
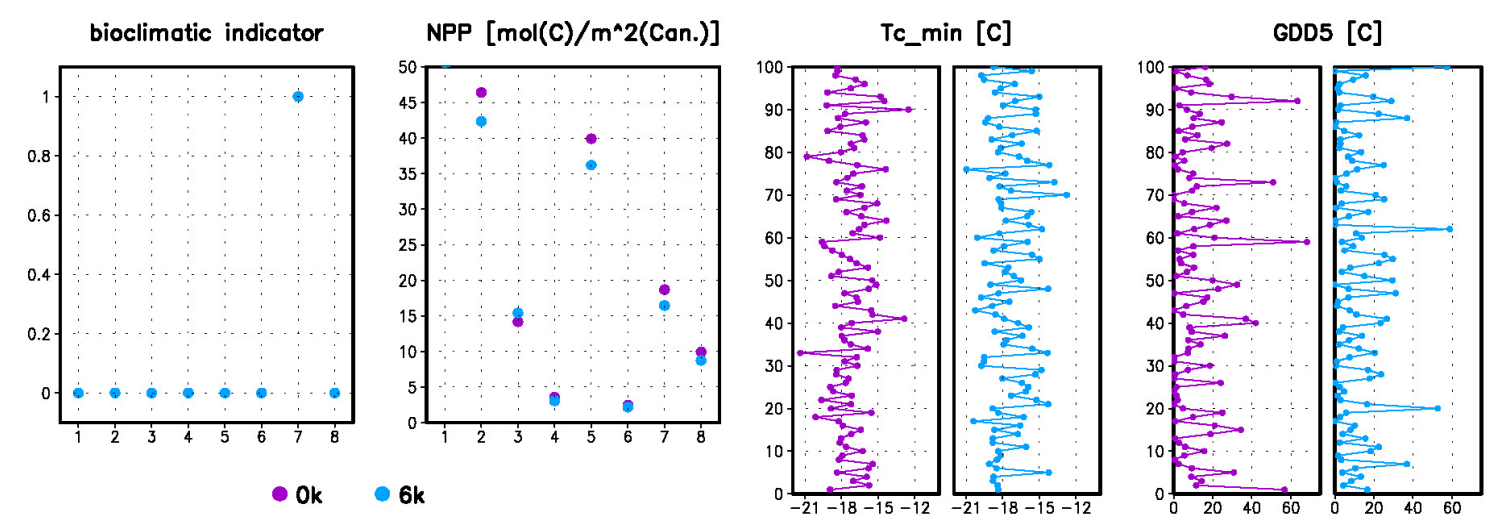

Fig. B7. Same as Fig. B5, but for the central Tibetan Plateau. 

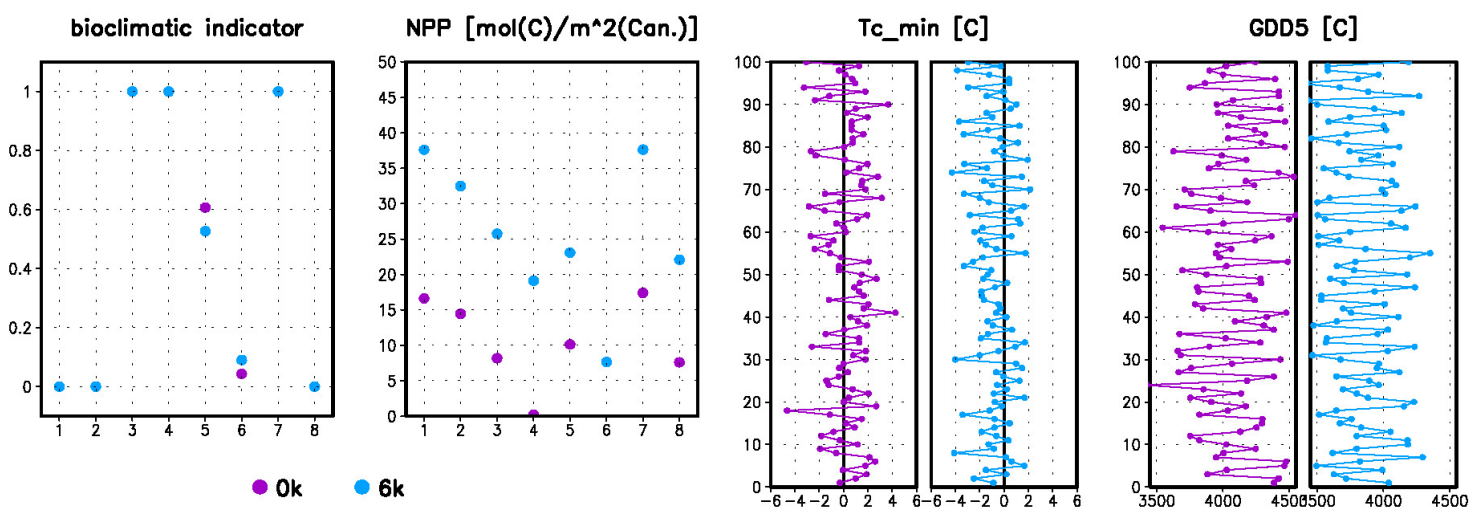

Fig. B8. Same as Fig. B5, but for the central-western Tibetan Plateau.

be attributed to the decreasing precipitation and the accompanying decrease in evaporative cooling at the latter sites that counteracts the temperature-decline resulting from the decreasing solar insolation from mid-Holocene to present-day in the summer season of the Northern Hemisphere.

The simulated change in the bioclimatic relevant parameters and the net primary productivity (NPP) is displayed in Figs. B5-B8. The bioclimate and NPP determine the distribution of the different plant functional types (PFTs) in the model. Whereas the bioclimate defines the grid-boxes where the PFTs can grow, the NPP controls the competition of the woody PFTs. In a favourable bioclimate, the woody PFT with the highest NPP is the dominant vegetation-type in the grid-box. The bioclimate indicator in Figs. B5-B8 quantifies how suitable the simulated climate in the different region on the Tibetan Plateau is. On the north-eastern Tibetan Plateau, bioclimatic conditions allow the growing of extratropical trees, cold shrubs, and C3 grass only. For these PFTs, the bioclimate is more favourable during mid-Holocene than at present-day. This is related to the bioclimatic limit of growing degree days that is not permanently exceeded any more in the colder present-day climate on the north-eastern Tibetan Plateau. On the south-eastern Tibetan Plateau, simulated bioclimatic conditions are perfect for the growing of extratropical trees and $\mathrm{C} 3$ grass during mid-Holocene as well as present-day. For raingreen shrubs, the bioclimatic conditions become more favourable in the course of the Holocene, since frost-events occur less often at present-day than at midHolocene $\left(\mathrm{Tc}_{\mathrm{min}}\right)$. The simulated climate on the central Tibetan Plateau is too cold to allow the establishment of woody PFTs in the model. C3 grass is the only PFT that can survive. On the central-western Tibetan Plateau, the growing of extratropical trees and $\mathrm{C} 3$ grass is not limited by the simulated bioclimate during the entire simulation. The establishment of shrubs are partly limited by frost. The decreasing precipitation leads to a halving of the simulated NPP from mid-Holocene to present-day.

\section{Appendix C}

\section{Assignment of the Biome-taxon to the simulated vegetation types}

Table C1. Assignment of the pollen-taxa to the major vegetation types in the model.

\begin{tabular}{|c|c|c|c|c|}
\hline & forest & shrub & $\begin{array}{l}\text { steppe/ } \\
\text { meadow }\end{array}$ & desert \\
\hline Alnus & 1 & 0 & 0 & 0 \\
\hline Betula & 1 & 0 & 0 & 0 \\
\hline Juniperus & 1 & 0 & 0 & 0 \\
\hline Picea & 1 & 0 & 0 & 0 \\
\hline Pinus & 1 & 0 & 0 & 0 \\
\hline Quercus & 1 & 1 & 0 & 0 \\
\hline Salix & 1 & 1 & 0 & 0 \\
\hline Thalictrum & 1 & 1 & 0 & 0 \\
\hline Rubiaceae & 1 & 1 & 1 & 0 \\
\hline Berberis & 0 & 1 & 0 & 0 \\
\hline Hippophaё & 0 & 1 & 0 & 0 \\
\hline Rhododendron & 0 & 1 & 0 & 0 \\
\hline Fabaceae & 0 & 1 & 0 & 0 \\
\hline Potentilla type & 0 & 1 & 0 & 0 \\
\hline Spiraea & 0 & 1 & 0 & 0 \\
\hline Apiaceae & 0 & 0 & 1 & 0 \\
\hline Bupleurum type & 0 & 0 & 1 & 0 \\
\hline Artemisia & 0 & 0 & 1 & 0 \\
\hline Chichorioideae & 0 & 0 & 1 & 0 \\
\hline Crassulaceae & 0 & 0 & 1 & 0 \\
\hline Cyperaceae & 0 & 0 & 1 & 0 \\
\hline Gentianaceae & 0 & 0 & 1 & 0 \\
\hline Lamiaceae & 0 & 0 & 1 & 0 \\
\hline Liliaceae & 0 & 0 & 1 & 0 \\
\hline Poaceae & 0 & 0 & 1 & 0 \\
\hline Rumex/Rheum & 0 & 0 & 1 & 0 \\
\hline Polygonum bistorta type & 0 & 0 & 1 & 0 \\
\hline Aconitum & 0 & 0 & 1 & 0 \\
\hline Ranunculus acris type & 0 & 0 & 1 & 0 \\
\hline Trollius type & 0 & 0 & 1 & 0 \\
\hline Stellera & 0 & 0 & 1 & 0 \\
\hline Anthemis type & 0 & 0 & 1 & 1 \\
\hline Aster type & 0 & 0 & 1 & 1 \\
\hline Saussurea & 0 & 0 & 1 & 1 \\
\hline Papaveraceae & 0 & 0 & 1 & 1 \\
\hline Brassicaceae & 0 & 0 & 0 & 1 \\
\hline Caryophyllaceae & 0 & 0 & 0 & 1 \\
\hline Chenopodiaceae & 0 & 0 & 0 & 1 \\
\hline Ephedra distachya type & 0 & 0 & 0 & 1 \\
\hline Ephedra fragilia type & 0 & 0 & 0 & 1 \\
\hline Calligonum & 0 & 0 & 0 & 1 \\
\hline Tamarix & 0 & 0 & 0 & 1 \\
\hline Nitraria & 0 & 0 & 0 & 1 \\
\hline
\end{tabular}


Acknowledgements. The authors would like to thank E. van Campo, Xingqi Liu and A. Kramer for their pollen data contribution. Furthermore, we would like to thank T. Kleinen, MPI-M, and T. Raddatz, MPI-M for constructive discussion and two anonymous reviewers for their helpful comments. This research is part of the priority program INTERDYNAMIK funded by the German Research Foundation (DFG). This study also contributes to the Cluster of Excellence CliSAP (Integrated Climate System Analysis and Prediction) funded by the German Federal Government and the German States.

The service charges for this open access publication have been covered by the Max Planck Society.

Edited by: D.-D. Rousseau

\section{References}

Adler, R. F., Huffman, G. J., Chang, A., Ferraro, R., Xie, P., Janowiak, J., Rudolf, B., Schneider, U., Curtis, S., Bolvin, D., Gruber, A., Susskind, J., and Arkin, P.: The Version 2 Global Precipitation Climatology Project (GPCP) Monthly Precipitation Anaysis (1979-Present), J. Hydrometeor., 4, 1147-1167, 2003.

Aldenderfer, M. S.: Modeling the Neolithic on the Tibetan Plateau, in: Late Quaternary climate change and human adaption in arid China, edited by: Madsen, D. B., Chen, F., and Gao, X., Developments in Quaternary Science, 151-166, 2007.

Aldenderfer, M. and Zhang, Y.: The prehistory of the Tibetan Plateau to the seventh century A.D.: perspectives and research from China and the West since 1950, J. World Prehist., 18, 1-55, 2004.

Asnani, G. C.: Tropical meteorology, published by G. C. Asnani, c/o Indian Institute of Tropical Meteorology, Noble Printers, Pashan, Pune-411008, India, 1202 pp., (2 vols.), 1993.

Birks, H. J. B. and Birks, H. H.: Quaternary Palaeoecology, Edward Arnold, London, 289 pp., 1980.

Brantingham, P. J. and Gao, X.: Peopling of the northern Tibetan Plateau, World Archaeol., 38, 387-414, 2006.

Broström, A., Coe, M., Harrison, S. P., Gallimore, R., Kutzbach, J. E., Foley, J. A., Prentice, I. C., and Behling, P.: Land surface feedbacks and palaeomonsoons in northern Africa, Geophys. Res. Lett., 25(19), 3615-3618, 1998.

Brovkin, V., Raddatz, T., Reick, C. H., Claussen, M., and Gayler, V.: Global biogeophysical interactions between forest and climate, Geophys. Res. Lett., 36, L07405, doi:10.1029/2009GL037543, 2009.

Claussen, M. and Gayler, V.: The greening of Sahara during the mid-Holocene: Results of an interactive atmosphere - biome model, Global Ecol. Biogeogr., 6, 369-377, 1997.

Claussen, M., Brovkin, V., and Ganopolski, A.: Biogeophysical versus biogeochemical feedbacks of large-scale land cover change, Geophys. Res. Lett., 28(6), 1011-1014, 2001.

Cour, P., Zheng, Z., Duzer, D., Calleja, M., and Yao, Z.: Vegetational and climatic significance of modern pollen rain in northwestern Tibet, Rev. Palaeobot. Palyno., 104, 183-204, 1999.

Cui, X. and Graf, H.F.: Recent land cover changes on the Tibetan Plateau: a review, Climate Change, 94, 47-61, 2009.

Cui, X., Graf, H. F., Langmann, B., Chen, W., and Huang, R.: Climate impacts of anthropogenic land use changes on the Tibetan
Plateau, Global Planet. Change, 54, 33-56, 2006.

Dallmeyer, A., Claussen, M., and Otto, J.: Contribution of oceanic and vegetation feedbacks to Holocene climate change in monsoonal Asia, Clim. Past, 6, 195-218, doi:10.5194/cp-6-1952010, 2010.

Dearing, J. A., Jones, R. T., Shen, J., Yang, X., Boyle, J. F., Foster, G. C., Crook, D. S., and Elvin, M. J. D.: Using multiple archives to understand past and present climate-human-environment interactions: the lake Erhai catchment, Yunnan Province, China, J. Paleolimnol., 40, 3-31, 2008.

Diffenbaugh, N. S. and Sloan, L. C.: Global climate sensitivity to land surface change: The mid Holocene revisited, Geophys. Res. Lett., 29(10), 1476, doi:10.1029/2002GL014880, 2002.

Duan, A. and Wu, G. X.: Role of the Tibetan Plateau thermal forcing in the summer climate pattern over subtropical Asia, Clim. Dynam., 24, 793-807, 2005.

Fang, J., Chen, A., Peng, C., Zhao, S., and Ci, L.: Changes in forest biomass carbon storage in China between 1949 and 1998, Science, 292, 2320, doi:10.1126/science.1058629, 2001.

Fischer, N. and Jungclaus, J. H.: Evolution of the seasonal temperature cycle in a transient Holocene simulation: orbital forcing and sea-ice, Clim. Past Discuss., 7, 463-483, doi:10.5194/cpd-7463-2011, 2011.

Fleitmann, D., Burns, S. J., Mudelsee, M., Neff, U., Kramers, J., Mangini, A., and Matter, A.: Holocene forcing of the Indian monsoon recorded in a stalagmite from Southern Oman, Science, 300, 1737-1739, 2003.

Fontes, J., Gasse, F., and Gibert, E.: Holocene environmental changes in Lake Bangong basin (Western Tibet). Part 1: Chronology and stable isotopes of carbonates of a Holocene lacustrine core, Palaeogeogr. Palaeocl., 120 (1-2), 25-47, 1996.

Gaillard, M.-J., Sugita, S., Mazier, F., Trondman, A.-K., Broström, A., Hickler, T., Kaplan, J. O., Kjellström, E., Kokfelt, U., Kuneš, P., Lemmen, C., Miller, P., Olofsson, J., Poska, A., Rundgren, M., Smith, B., Strandberg, G., Fyfe, R., Nielsen, A. B., Alenius, T., Balakauskas, L., Barnekow, L., Birks, H. J. B., Bjune, A., Bjrkman, L., Giesecke, T., Hjelle, K., Kalnina, L., Kangur, M., van der Knaap, W. O., Koff, T., Lagerås, P., Latalowa, M., Leydet, M., Lechterbeck, J., Lindbladh, M., Odgaard, B., Peglar, S., Segerström, U., von Stedingk, H., and Seppä, H.: Holocene land-cover reconstructions for studies on land coverclimate feedbacks, Clim. Past, 6, 483-499, doi:10.5194/cp-6483-2010, 2010.

Gasse, F., Arnold, M., Fontes, J. Ch., Fort, M., Gibert, E., Huc, A., Bingyan, L., Yuanfang, L., Qing, L., Mélières, F., Van Campo, E., Fubao, W., and Qingsong, Z.: A 13000 yr climate record from Western Tibet, Nature, 353, 742_-745, doi:10.1038/353742a0, 1991.

Gehrig, R. and Peeters, A. G.: Pollen distribution at elevations above $1000 \mathrm{~m}$ in Switzerland, Aerobiologia, 16, 69-74, 2000.

Herzschuh, U. and Birks, J.: Evaluating the indicator value of Tibetan pollen taxa for modern vegetation and climate, Rev. Palaeobot. Palyno, 160, 197-208, 2010.

Herzschuh, U., Winter, K., Wünnemann, B., and Li, S.: A general cooling trend on the central Tibetan Plateau throughout the Holocene recorded by the Lake Zigetang pollen spectra, Quat. Int., 154-155, 113-121, 2006.

Herzschuh, U., Birks, H. J. B., Ni, J., Zhao, Y., Liu, H., Liu, X., and Grosse, G.: Holocene land-cover changes on the Tibetan Plateau, 
The Holocene, 20, 91-104, 2010a.

Herzschuh, U., Birks, H. J. B., Mischke, S., Zhang, C., and Böhner, J.: A modern pollen-climate calibration set based on lake sediments from the Tibetan Plateau and its application to a Late Quaternary pollen record from the Qilian Mountains, J. Biogeogr., $37,752-766,2010 b$

Hou, X. (chief ed.): Vegetation atlas of China, Science Press, Beijing, 2001.

Hsu, H.-H. and Liu, X.: Relationship between the Tibetan Plateau heating and East Asian summer monsoon rainfall, Geophys. Res. Lett., 30(20), 2066, doi:10.1029/2003GL017909, 2003.

Jacobson Jr., G. L. and Bradshaw, R. H. W.: The selection of sites for paleovegetational studies, Quat. Res., 16, 80-96, 1981.

Jungclaus, J. H., Botzet, M., Haak, H., Keenlyside, N., Luo, J.J., Latif, M., Marotzke, J., Mikolajewicz, U., and Roeckner, E.: Ocean circulation and tropical variability in the coupled model ECHAM5/MPI-OM, J. Climate, 19, 3952-3972, 2006.

Kleinen, T., Tarasov, P., Brovkin, V., Andreev, A., and Stebich, M.: Comparison of modeled and reconstructed changes in forest cover through the past 8000 years: Eurasian perspective, The Holocene, 21(5), 723-734, doi:10.1177/0959683610386980, 2011

Kramer, A., Herzschuh, U., Mischke, S., and Zhang, C.: Holocene treeline shifts and monsoon variability in the Hengduan Mountains (southeastern Tibetan Plateau), implications from palynological investigations, Palaeogeogr. Palaeocl., 286(1-2), 23-41, 2010

Levis, S., Bonan, G. B., and Bonfils, C.: Soil feedback drives the mid-Holocene North African monsoon northward in fully coupled CCSM2 simulations with a dynamic vegetation model, Clim. Dynam., 23, 791-802, 2004.

Li, Y., Harrison, S., Zhao, P., and Ju, J.: Simulations of the impact of dynamic vegetation on interannual and interdecadal variability of Asian summer monsoon with modern and mid-Holocene orbital forcings, Global Planet. Change, 66(3/4), 235-252, 2009.

Liu, X., Shen, J., Wang, S., Wang, Y., and Liu, W.: Southwest monsoon changes indicated by oxygen isotop of ostracode shells from sediments in Qinghai Lake since the late Glacial, Chinese Sci. Bull., 52, 539-544, 2007.

Liu, Y. M., Bao, Q., Duan, A. M., Qian, Z. A., and Wu, G. X.: Recent progress in the impact of the Tibetan Plateau on climate in China, Adv. Atmos. Sci., 24, 1060-1076, 2007.

Maher, B. A.: Holocene variability of the East Asian summer monsoon from Chinese cave records: a re-assessment, The Holocene, 18(6), 861-866, 2008.

Markgraf, V.: Pollen dispersal in a mountain area, Grana, 19, 127 146, 1980.

Marsland, S. J., Haak, H., Jungclaus, J. H., Latif, M., and Roske, F.: The Max-Planck-Institute global ocean/sea ice model with orthogonal curvilinear coordinates, Ocean Modell., 5, 91-127, 2003.

Miller, P. A., Giesecke, T., Hickler, T., Bradshaw, R. H. W., Smith, B., Seppä, H., Valdes, P. J., and Sykes, M. T.: Exploring climatic and biotic controls on Holocene vegetation change in Fennoscandia, J. Ecol., 96, 247-259, doi:10.1111/j.13652745.2007.01342.x, 2008.

Prentice, I. C., Guiot, J., Huntley, B., Jolly, D., and Cheddadi, R.: Reconstructing biomes from palaecological data: a general method and its application to European pollen data at 0 and $6 \mathrm{ka}$,
Clim. Dynam., 12, 185-194, 1996.

Raddatz, T. J., Reick, C. H., Knorr, W., Kattge, J., Roeckner, E., Schnur, R., Schnitzler, K.-G., Wetzel, P., and Jungclaus, J.: Will the tropical land biosphere dominate the climate-carbon cycle feedback during the twenty-first century?, Clim. Dynam., 29, 565-574, 2007.

Ren, G.: Decline of the mid- to late Holocene forests in China: climatic change or human impact?, J. Quat. Sci., 15(3), 273-281, 2000.

Rhode, D., Zhang, H. Y., Madsen, D. B., Xing, G., Brantingham, R. J., Ma, H. Z., and Olsen, J. W.: Epipaleolithic/early Neolithic settlements at Qinghai Lake, western China, J. Archaeol. Sci., 34, 600-612, 2007.

Rodwell, M. and Hoskins B.: Monsoons and the dynamics of deserts, Q. J. Roy. Meteor. Soc., 122, 1385-1404, 1996.

Roeckner, E., Bäuml, G., Bonaventura, L., Brokopf, R., Esch, M., Giorgetta, M., Hagemann, S., Kirchner, I., Kornblueh, L., Manzini, E., Rhodin, A., Schlese, U., Schultzweida, U., and Tompkins, A.: The atmospheric general circulation model ECHAM5. Part I: Model description. MaxPlanckInst. f. Meteor., Report No. 349, Hamburg, 2003.

Schlütz, F. and Lehmkuhl, F.: Holocene climatic change and the nomadic Anthropocene in Eastern Tibet: palynological and geomorphological results from the Niabooyeze Mountains, Quaternary Sci. Rev., 28, 1449-1471, doi:10.1016/j.quascirev.2009.01.009, 2009.

Shen, J., Liu, X., Wang, S., and Ryo, M.: Paleoclimatic changes in the Qinghai Lake area during the last 18.000 years, Quat. Int., 136, 131-140, 2005.

Shen, J., Jones, R. T., and Yang, X.: The Holocene vegetation history of Lake Erhai, Yunnan Province southwestern China: the role of climate and human forcings, The Holocene, 16, 265-276, 2006.

Simmons, A. J. and Gibson, J. K.: The ERA-40 Project Plan, ERA40 Project Report Series No. 1 ECMWF. Shinfield Park, Reading, UK, 63 pp., 2000.

Sun, H. (chief editor): The national physical atlas of China. China Cartographic Publishing House, 230 pp., 1999.

Sitch, S., Smith, B., Prentice, I. C., Arneth, A., Bondeau, A., Cramer, W., Kaplan, J. O., Levis, S., Lucht, W., Sykes, M. T., Thonicke, K., and Venevsky, S.: Evaluation of ecosystem dynamics, plant geography and terrestrial carbon cycling in the LPJ dynamic global vegetation model, Glob. Change Biol., 9, 161185, 2003.

Studley, J.: Forests and environmental degradation in SW China, Int. For. Rev., 1, 260-265, 1999.

Tang, L. Y., Shen, C. M., Li, C. H., Peng, J. L., Liu, H., Liu, K. B., Morrill, C., Overpeck, J. T., Cole, J. E., and Bao, Y. Pollen-inferred vegetation and environmental changes in the central Tibetan Plateau since 8200 yr BP, Sci China Ser D-Earth Sci., 52(8), 1104-1114, doi:10.1007/s11430-009-0080-5, 2009.

Ueno, K., Fujii, H., Yamada, H., and Liu, L.: Weak and frequent monsoon precipitation over the Tibetan Plateau, J. Meteorol. Soc. Jpn, 79(1B), 419-434, 2001.

Van Campo, E., Cour, P., and Sixuan, H.: Holocene environmental changes in Bangong Co basin (Western Tibet). Part 2: The pollen record. Palaeogeogr. Palaeocl., 120(1-2), 49-63, 1996.

Wang, B., Bao, Q., Hoskins, B., Wu, G. X., and Liu, Y.: Tibetan Plateau warming and precipitation changes in East Asia, Geo- 
phys. Res. Lett., 35(14), L14702, doi:10.1029/2008GL034330, 2008.

Wang, Y. J., Cheng, H., Edwards, R. L., He, Y. Q., Kong, X. G., An, Z. S., Wu, J. Y., Kelly, M. J., Dykoski, C. A., and Li, X. D.: The Holocene Asian monsoon: Links to solar changes and North Atlantic climate, Science, 308, 854-857, 2005.

Wischnewski, J., Mischke, S., Wang, Y., and Herzschuh, U.: Reconstructing climate variability on the northeastern Tibetan Plateau since the last Lateglacial - a multi-proxy, dual-site approach comparing terrestrial and aquatic signals, Quaternary Sci. Rev., 30(1-2), 82-97, 2011.

Wohlfahrt, J., Harrison, S. P., Braconnot, P., Hewitt, C. D., Kitoh, A., Mikolajewicz, U., Otto-Bliesner, B. L., and Weber, S. L.: Evaluation of coupled ocean-atmosphere simulations of the mid-Holocene using palaeovegetation data from the northern hemisphere extratropics, Clim. Dynam., 31, 871-890, doi:10.1007/s00382-008-0415-5, 2008.

Wu, G. X.: Recent advances in Qinghai-Xizhang-Plateau climate dynamic research, Quarterly Sci., 24(1), 1-9, 2004 (in Chinese).

Wu, G. X. and Zhang, Y. S.: Tibetan Plateau forcing and the timing of the monsoon onset over South Asia and the South China Sea, Mon. Weather Rev., 126, 913-927, 1998.

Wu, G. X., Wang, J., Liu, X., and Liu, Y. M.: Numerical modelling of the influence of Eurasian orography on the atmospheric circulation in different seasons, Acta Meteorol. Sin., 63(5), 603-612, 2005 (in Chinese).

Wu, G. X., Liu, Y. M., Wang, T. M., Wan, R., Liu, X., Li, W., Wang, Z., Zhang, Q., Duan, A., and Liang, X.: The influence of the mechanical and thermal forcing of the Tibetan plateau on the Asian climate, J. Hydrometeorol., 8, 770-789, 2007.
Xu, H., Hou, Z. H., Ai, L., and Tan, L. C.: Precipitation at Lake Qinghai, NE Qinghai-Tibet Plateau, and its relation to Asian summer monsoons on decadal/interdecadal scales during the past 500 years, Palaeogeogr. Palaeocl., 254, 541-549, 2007.

Yanai, M. and Wu, G. X.: Effects of the Tibetan Plateau. The Asian Monsoon, B. Wang, Ed., Springer, 513-549, 2006.

Yasunari, T.: Role of Land-Atmosphere Interaction on Asian Monsoon Climate, J. Meteorol. Soc. Jpn., 85B, 55-75, 2007.

Ye, D. Z. and Wu, G. X.: The role of the heat source of the Tibetan Plateau in the general circulation, Meteorol. Atmos. Phys., 67, 181-198, 1998.

Yu, G., Prentice, I. C., Harrison, S. P., and Sun, X.: Pollen-based biome reconstruction for China at 0 and 6000 years, J. Biogeogr., 25, 1055-1069, 1998

Yu, G., Chen, X., Ni, J., Cheddadi, R., Guiot, J., Han, H., Harrison, S. P., Huang, C., Ke, M., Kong, Z., Li, S., Li, W., Liew, P., Liu, G., Liu, J., Liu, Q., Liu, K.-B., Prentice, I. C., Qui, W., Ren, G., Song, C., Sugita, S., Sun, X., Tang, L., Van Campo, E., Xia, Y., Xu, Q., Yan, S., Yang, X., Zhao, J., and Zheng, Z.: Palaeovegetation of China: a pollen date-based synthesis for the mid-Holocene and last glacial maximum, J. Biogeogr., 27, 635664, 2000.

Zhang, P., Shao, G., Zhao, G., Le Master, D., Parker, G., Dunning Jr., J., and Li, Q.: Ecology: China's forest policy for the 21 st century, Science, 288, 2135, doi:10.1126/science.288.5474.2135, 2000.

Zhang, Q. Y., Jin, Z. H., and Peng, J. B.: The relationship between convection over the Tibetan Plateau and circulation over East Asia, Chinese J. Atmos. Sci., 30, 802-812, 2006 (in Chinese). 